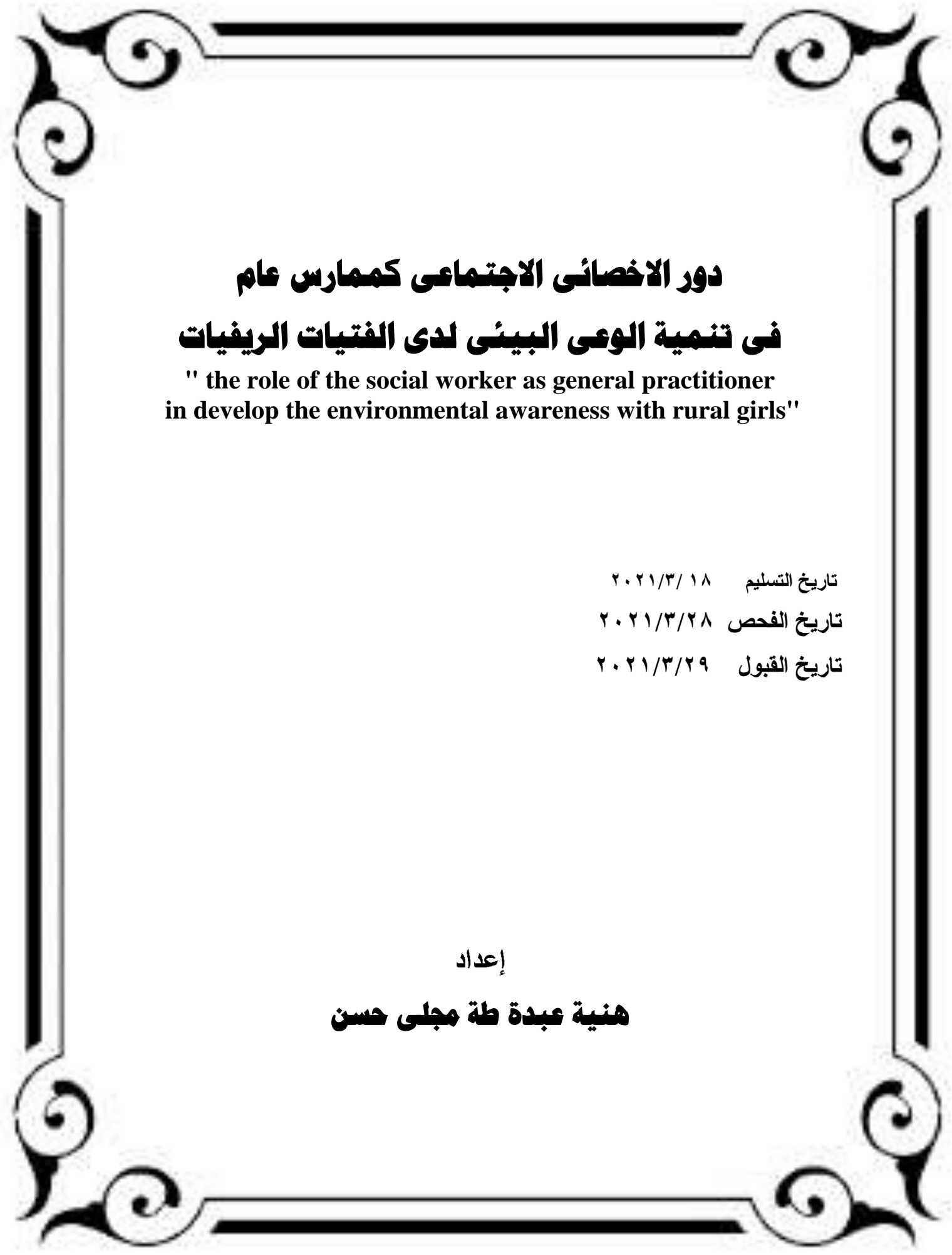





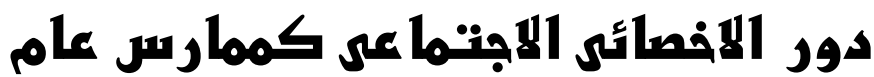

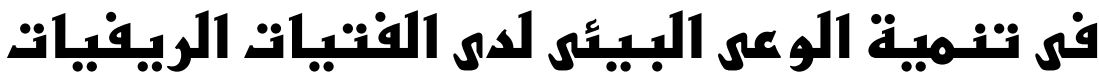

\section{اعداد وتنفيد}

\section{هنية عبدة طة مبلى هسن}

البيئه هى الاطار الأى يعيش فيه الاسسان وويبين فيه سكنه,ويقيم صناعته,ويمد فيه طرق وسـيله

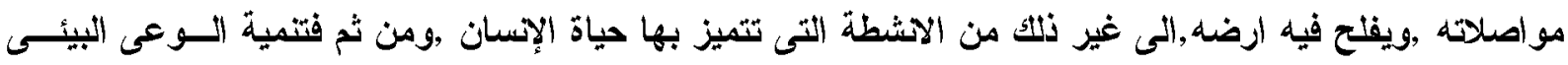

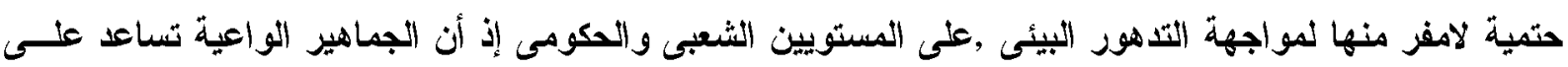

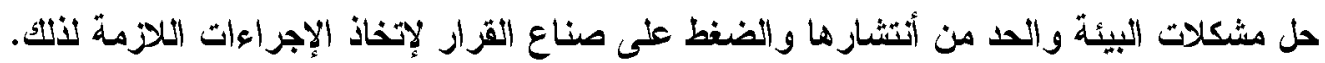

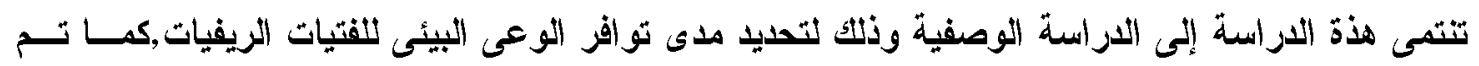

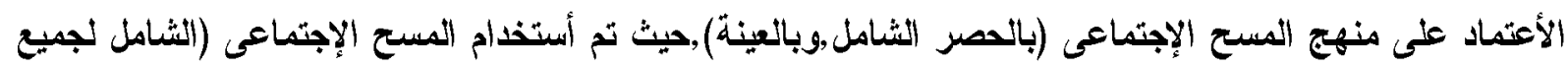

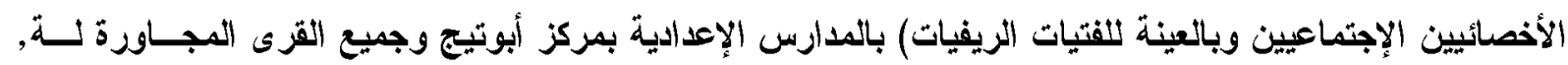

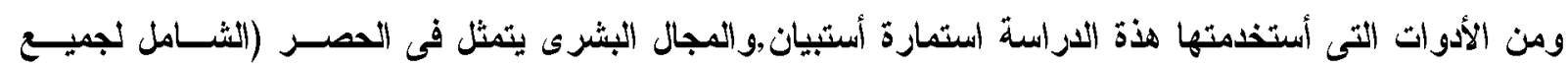

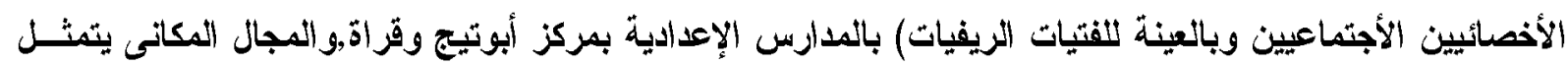

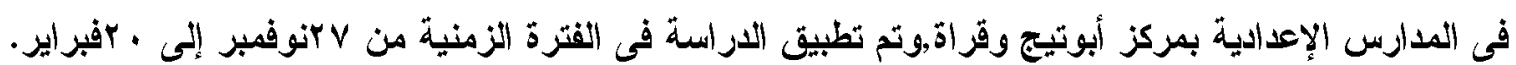

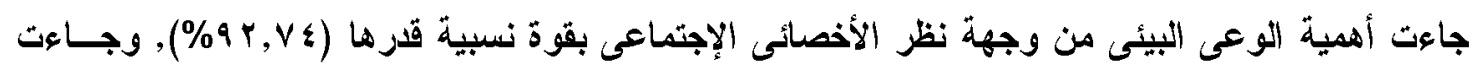

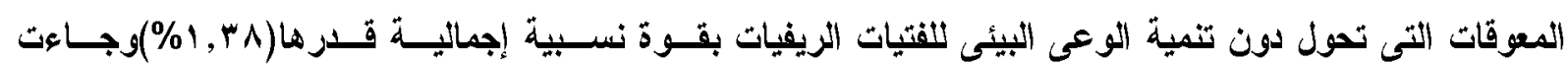

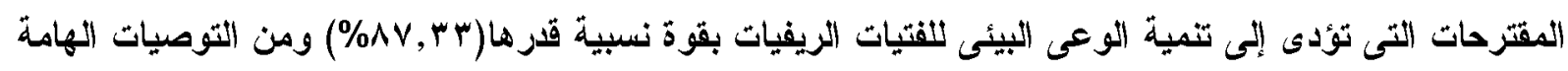

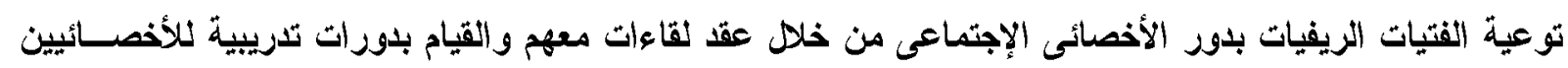

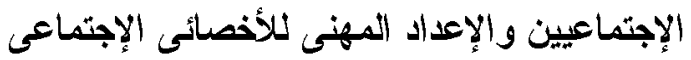

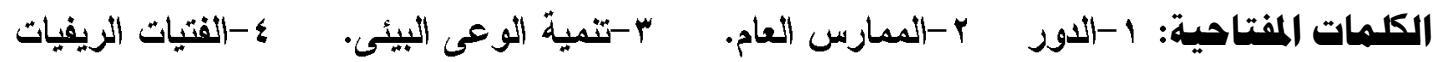




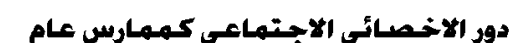

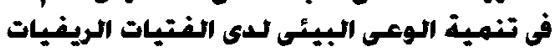
هنية عبدة طنة مجلى حسن لهن
المجلة العلمية للخدمة الاجتماعية

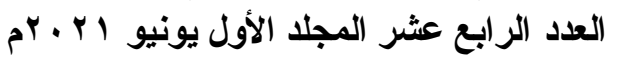

" the role of the social worker as general practitioner in develop the environmental awareness with rural girls"

\section{Abstract}

The environment is where you live, and thus developing environmental awareness is an inevitable imperative to confront environmental degradation, at the public and governmental levels, as the conscious masses help solve environmental problems and limit their spread and pressure decision- makers to take the necessary measures for that.

This study belongs to the descriptive study in order to determine the extent of the environmental awareness of rural girls. Also, the social survey methodology (comprehensive enumeration, and by sample) was used, where the social survey (comprehensive for all social workers and by sample for rural girls) was used in preparatory schools in the Abbottie Center and all neighboring villages. Therefore, one of the tools used by this study is a questionnaire form, and the human field is the enumeration (comprehensive for all social workers and the sample for rural girls) in preparatory schools in the Abu Tig and Qaraat center, and the spatial field is in the preparatory schools in the Abu Tig and Qaraat center, and the study was applied in the time period from November 27 to February 20.

The importance of environmental awareness came from the viewpoint of the social worker with a relative strength of $(92.74 \%)$. The obstacles that prevent the development of environmental awareness of rural girls came with a total relative strength of $(1.38 \%)$. The proposals that lead to the development of environmental awareness of rural girls came strongly. A proportional ratio of $(87.33 \%)$ and one of the important recommendations is to educate rural girls about the role of the social worker by holding meetings with them and conducting training courses for social workers and the professional preparation of the social worker

Key words:

1- role 2- General Practitioner. 3- Development of environmental awareness. 4- Rural girls 


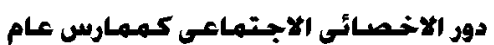

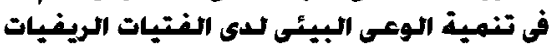

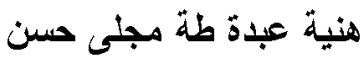

الأهنمام بالتفيات الريفيات يعد من المعـاييز المهـــة

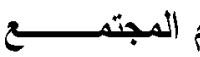

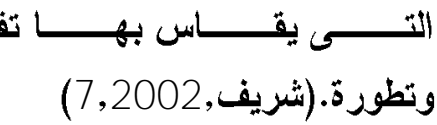

لذا فإن العناية بالفتيات الريفيات ورعايتهم مسن التصن النواحى الجسمية والعقلية والإجتماعية هى ضرورية

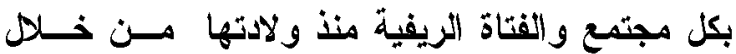

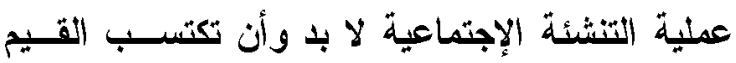
والعادات والتقاليد وثقافة المجنمع الأثى تعيش فيــة.

( على, (77,2008)

ليس هناك من دليل ثوث على أستمراز حالــة

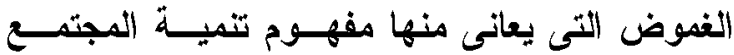
المحلى حتى الآن من وجود زلتك العـدـد الكبيـر مسن التعريفات لتنمية المجتمع المحلى فى الكتابات المهنية ولعل هذا هو ما دفع كرسـتنون وروســنون للقيـام بدراسة تم فيها تحليل لمحتوى جيع أعـداد مجلـة فرسة جمية تنمية المجتمع المحلى. (شوقى,16,1998 ) حيث بـرزت قضــية التنميـة الإجتماعيـة للمجتمعات الريفية فى الفكر الإجتماعى نتيجة لظروف واقعية قابلتها المجتمعات النامية بين سكانها بالإضافة إلى سوء الحالة الصحية والإجتماعية. (سيد,2002 , 357) وهذا ما أتفقت علية دراســة teksoz and (2012)etal والتى وضحت أن نموذج مكونات محو

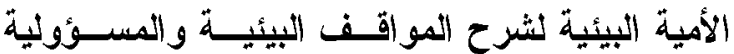

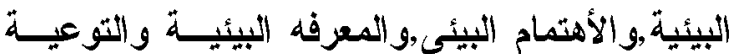

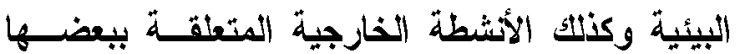
البعض فى البيئة,وتوصلت إلى إعطاء أدلـــة لإيجــاد إجابة على السؤال"كيف يمكن تطبيق الوعى البيئى من أجل التنمية المستدامة فى مناهج التعليم العالى".

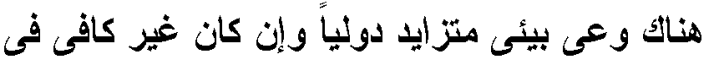

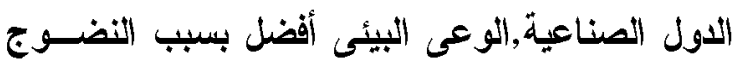

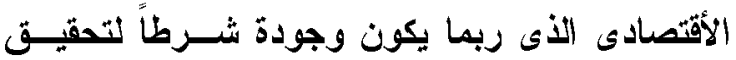

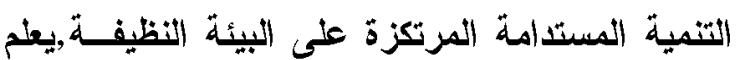

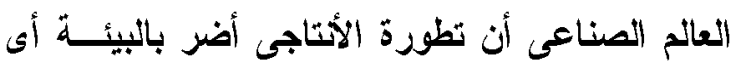

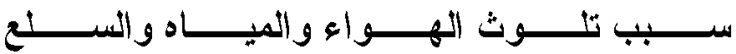

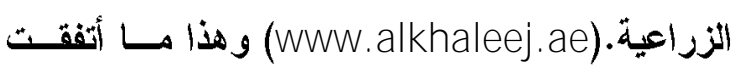

المجلة العلمية للخدمة الاجتماعية

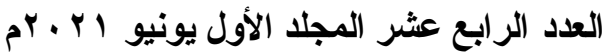

أولا : هشكلة الدراستة:

البيئه هى الاطار الأى يعيش فيه الأسان بويبين فيـه سكنه ,ويقيم صناعته ,ويمد فيه طرق وسياله مواصلاته الهيه

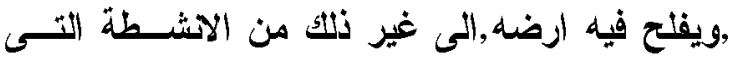
تثميز بها حياة الإنسان. (حجاب, 23,1999$)$ وإن المثكلة البيئية وبحجمها الزاهن ليســ

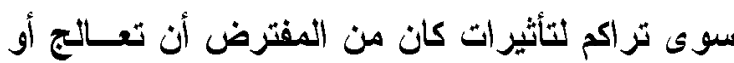
انها قصور فى الوعى البيئى حينها وتصنيف آليـات

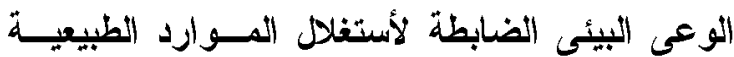

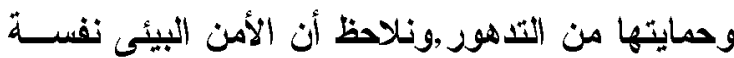
لايصل أهدافة في غياب الوعى البيئى لدى المجتمعات.

(الاسوقى, 79,2017 )

ولذلك فإن قـــة الأرض بريوديجـانيرو لقـــ

أهتمت بالقضية البيئية لعموم الكوكب وحضرها ل 10 رئيس دولة وملتك وقث جاءت هذة القمة بعـد مسرور عشرين عامأعلى مؤتمر الأمم المتحدة عـن البيئـة

والإنسان. (جميل, 70,2017 )

تعد قضية التنمية من القضايا المهمــة التهـ

تستحوذ على أهتـــام المجتمعسات كافـة المتقدهـة

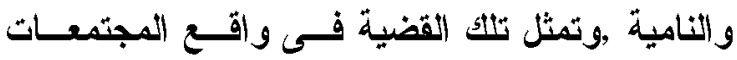

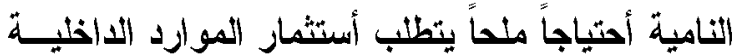

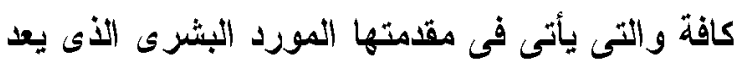

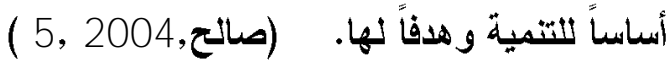

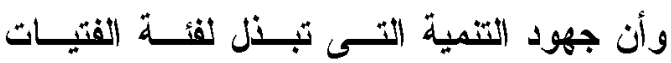
الريفيات في أى مجتمع من المجتمعات لها أهميتهـا

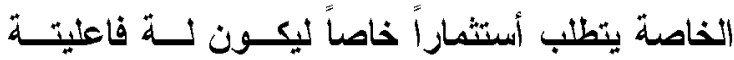

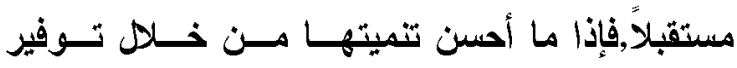

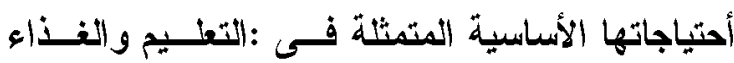
والصحة والرعاية الإجتماعية فإنة يتوقع لها أن نكون

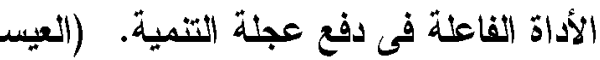
وآخرون, 211,1999

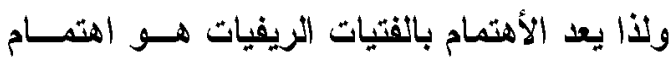

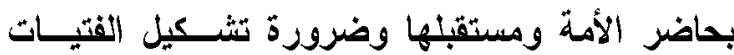

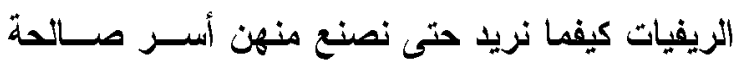

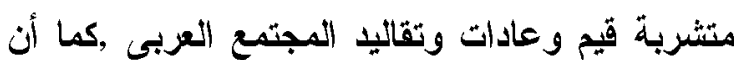




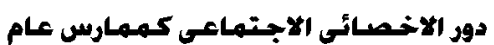

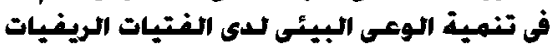

هنية عبدة طلة مجلى حسن المى لهن

للوعى البيئى مرتبطاً بمؤثرات التنميـة الإجتماعيـة والإقتصادية الأخرى على المستوى الوطنى.وتوصلت

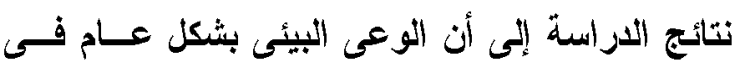

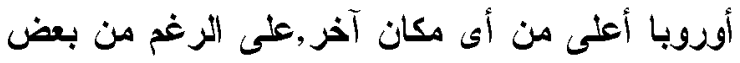

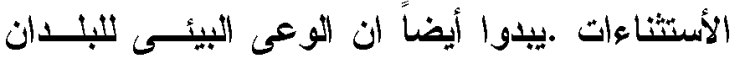

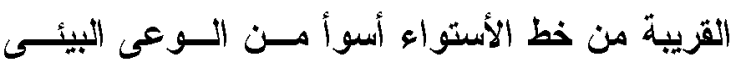
والحالة الراهنة للبيئة.أما الأرتباطات التى تم أختيارها

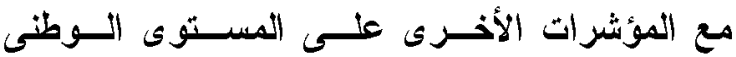
وتوصلت إلى أن الوعى البيئى مرتبط بثكل إيجـابـ.

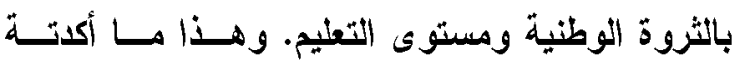

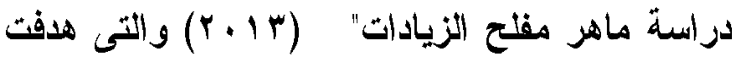
الاراسة الى الكثف عن مستوى اللوعى البيئى لـدى معلمى الاراسات الأجتماعية فى الأردن وتوصلت إلى الثى

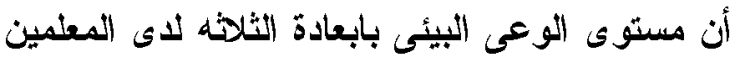

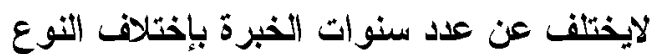
ولعبث الفتيات الريفيات دوراً هاماً فــى حيــاة المجتمعات العربية على مر التاريخ.فقد أعطت الكثير لأسرتها,والمجتمعها الريفى ولدولها العربية من خلا ما قامت بة من أدوار إجتماعية وإقتصــادية مثــرفة فئة

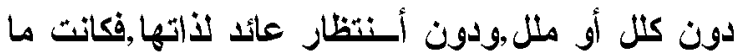
تتمناة فى عطائها توفير مناخ أســرى جيا روتحسـين معيشة أسرتها بشتى السبل وإعداد جيل من الأبنـاء

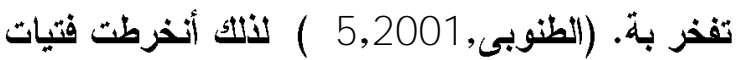

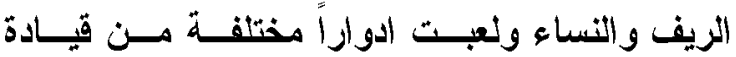
الميراث إلى تنظيمها.وهذا ما يكثف الطاقة الهائلــة

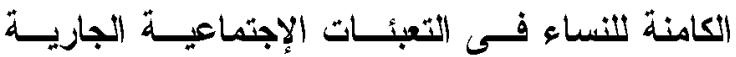

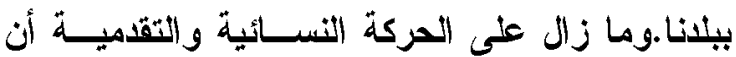
تعل على تحفيز المشاركة النسائية وفتح المجـالات والفضاءات للمساهمة في تنمية الوعى الجماعى مسن

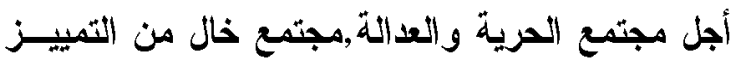

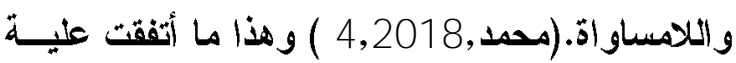

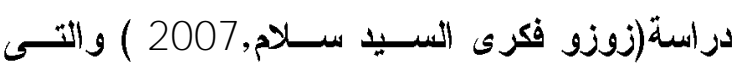

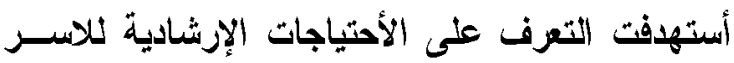

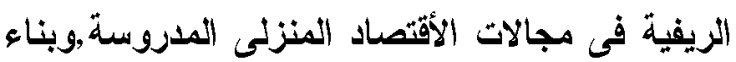
وتنفيذ برنامج إرشادى للفتيـات الريفيـات لأختبـار
علية دراسه(سالم الزهزانى,2007) حــول التعـرف

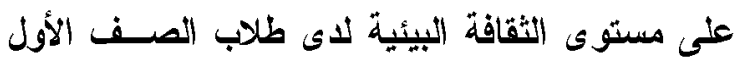

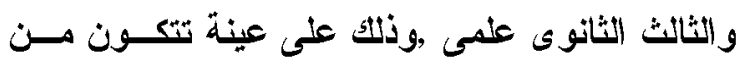

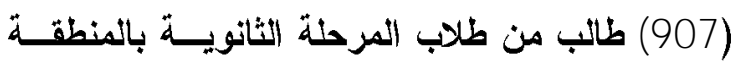
الغربية للمملكة السعودية ,أستخدمت الباحثة أختبـار

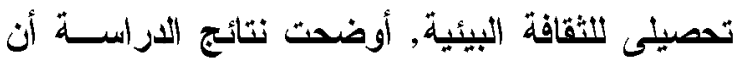
المعدل العام للثقافة البيئية لدى طــلاب الصــف الأول التهل والثالث الثانوى يقل عن معدل الكفاية علـى درجـة

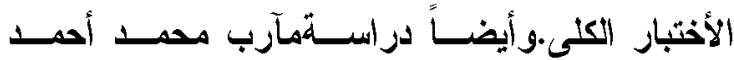

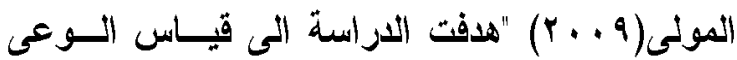
البيئى لاى طلبة كليه التربيه ولجميع الأقســام(على هل

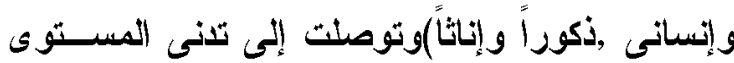
العام للوعى البيئ للثى طلبة كلية التربية

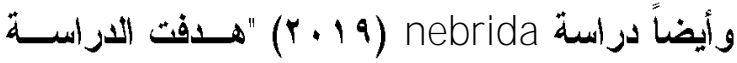
المى قياس مستوى التوعى والممارسات لاى 100 من

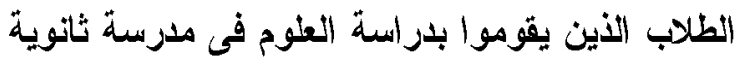

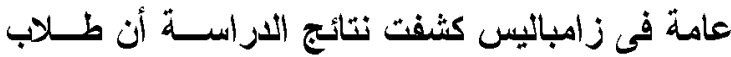
العلوم يلركون تمام الإدر الك المفاهيم البيئيسـة وحالــة

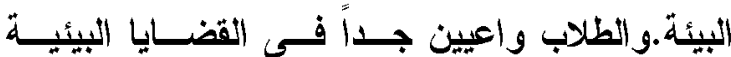
والمشاكل غالباً ما يتدربون على أتخاذ إجراءات لدهل المثكلات البيئية وأحياناً يمارسون الحاجة إلى إمتلاك

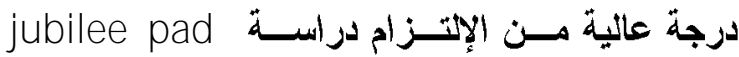

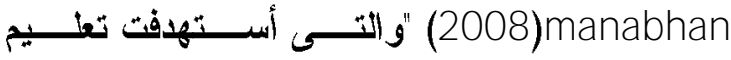
المعلمين من أجل تطوير الوعى الضرورى والموقــف والف

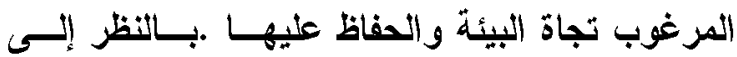
ضرورة المعرفة البيئية وتطبيقها مسن أجسل حمايسة

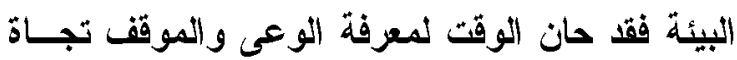

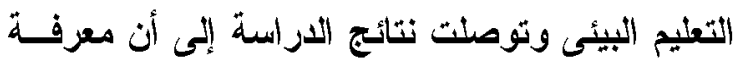

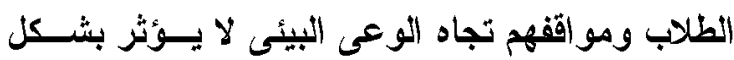

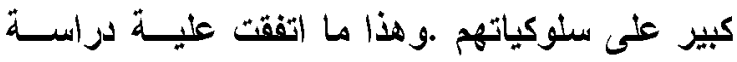
(2013)eevi kokkinen

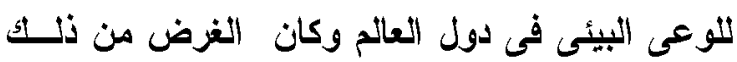

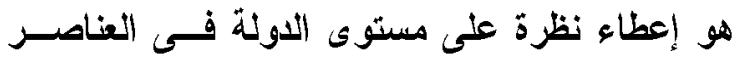

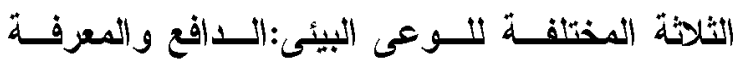
والمهارة.من المهتم أيضاً بمعرفة ما إذا كان قياســا 


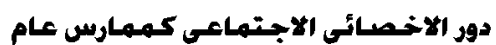

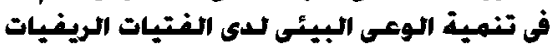

هنية عبدة طلة مجلى حسن المى لهن

التعليهى البيئى يؤدى إلى الوعى البيئى ويرف إلـــ

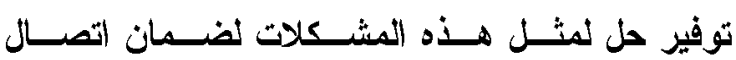

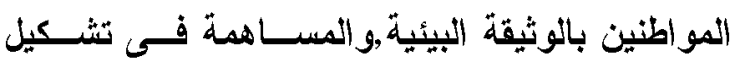
أنماط سلوك وأنثطة صديقة للبيئة, التشكيل مجموعـة فئة من المعرفة حول البيئة كنظام من العوامل الطبيعيـة مبهة

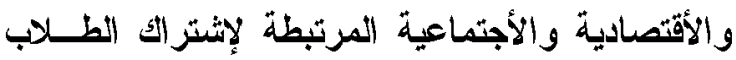
فى حل المشاكل البيئية وتوصلت إلى تصميم وتنفيــن المناهج وبرامج التشريب للتثيف البيأسى لكـل مسن التلاميذ و الكبار.

كما أنة يلعب دوراً حيوياً فــــ مســاعدة الإدارة

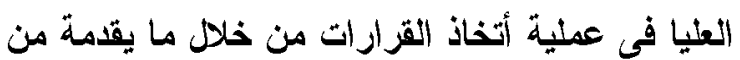
معلومات وحقائق تساعد المنظمة على تحليد المهـام والأهداف التى تسعى إلى تحقيقها بما يتلاثم مع كـلــل

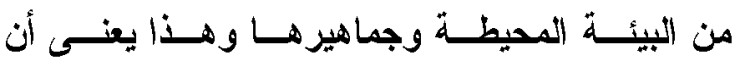
الممارس العام يسهم بشكل أساسى فى عملية صــنع

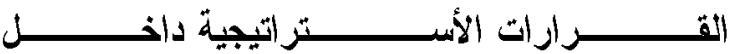

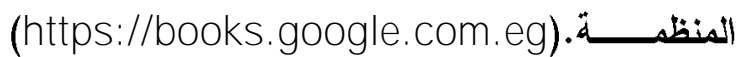

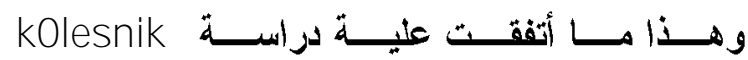
(2018)annal والتى اسـتهوفت تطبيـت أســاليب التدريب البيئ الخاصة بالتتوعية البيئية والمواقف.تم استخدام تقتياتنا الأصلية وتوصلت النتائج إلى تحفيـز النشاط الفكرى للطلاب فى هذا المجال المحددوتسهيل عملية تحديد الإمكانبات الثخصية وتفعيلها في مجـال الطبيعة و إدارة الموارد البيئية.

وفقاً لمنظور الممارسة العامة يمكنة أستخدام المداخل والطرق المختلفة في تعاملة مـعتستق العميل-

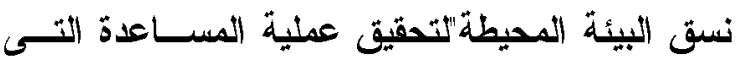
تتضمن الأفز اد, العائلات, الجماعات, المنظمــات.ويتث

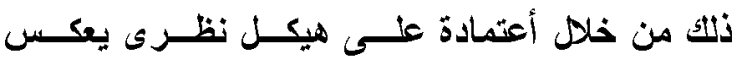
النظرية الحديثة والطرق و النماذج و المهار ات المناده لئاسبة لتطبيق الممارسة العامـة فـى الخدمــة الإجتماعيـة.

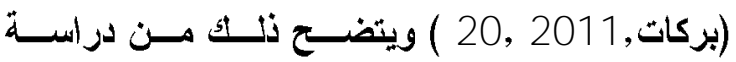
(2016)hsiao and etal و التى استّهوفت استخدام

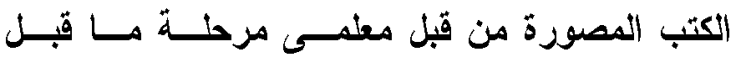

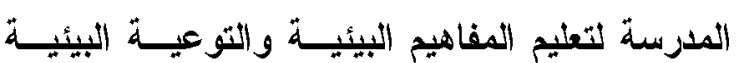

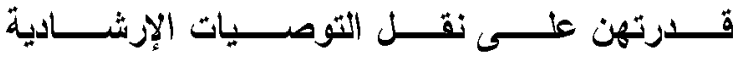

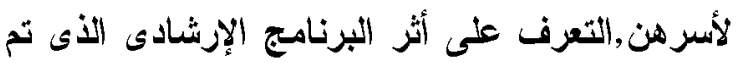

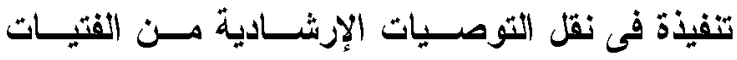

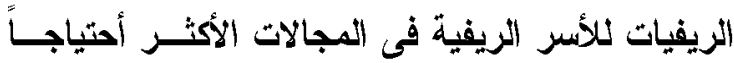

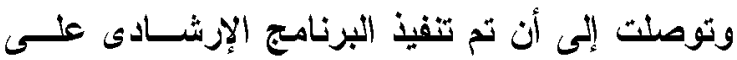

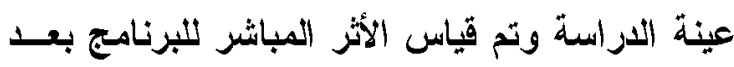

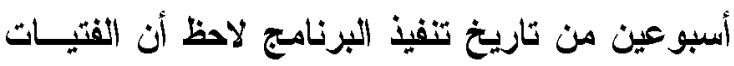

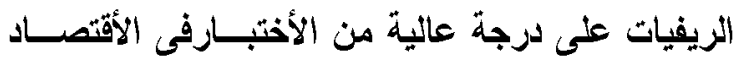

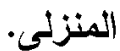

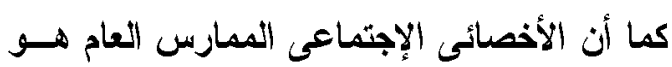

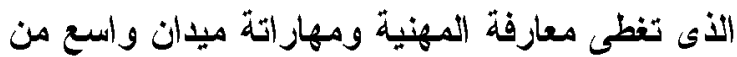

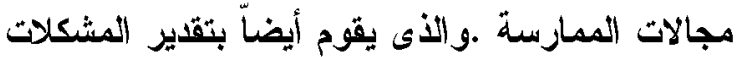

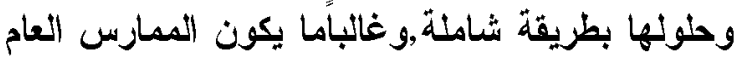

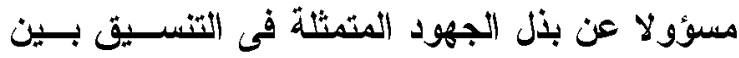
الأخصائى المتخصص و العميل مـن خـلال التحويسل وتسهيل عملية الأتصال فيما بينهما. (الـــخيل,2013

(103,

ويعمل الممارس العــام عـــ تنميـة

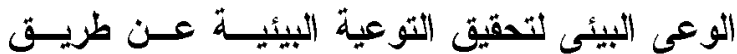
جميات حماية البيئة الضرورية بحيث توفر الظروف

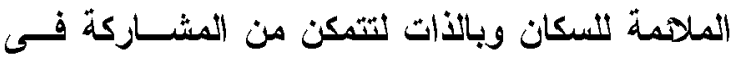

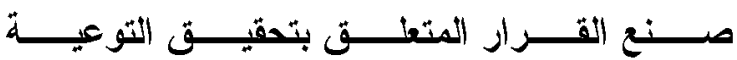

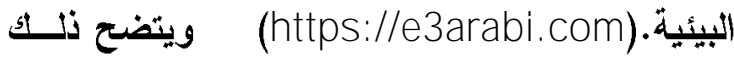

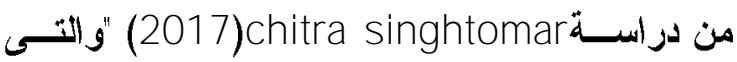
أستهدفت أن التعليم البيئى والأى عبارة عن التعـرف

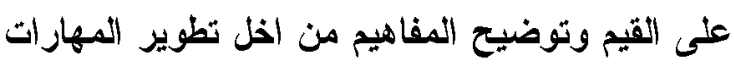

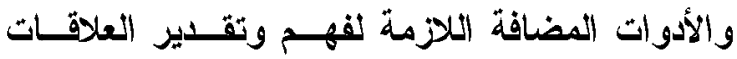
المتبادلة بين الإسسان وثثافتة ومحيطة البيوفيزيسائى الحيوى .من خلال هذا التعزيف من التواضع ان التعليم

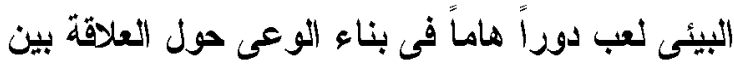

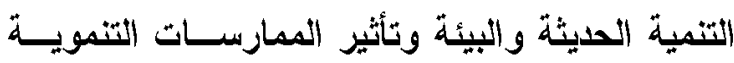

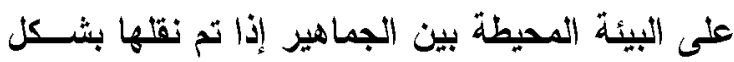

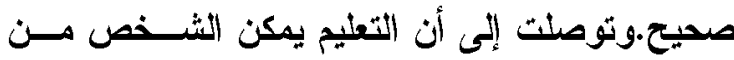

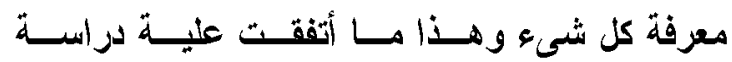

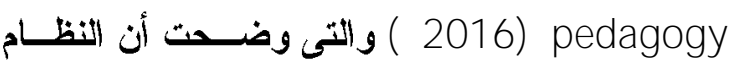




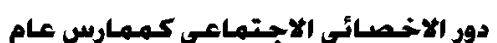

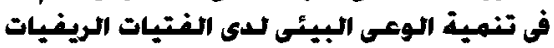

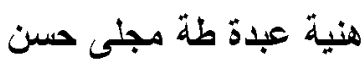

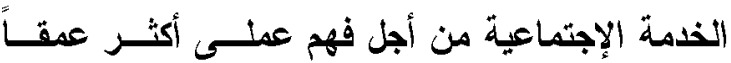

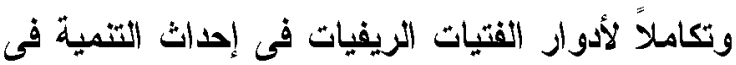

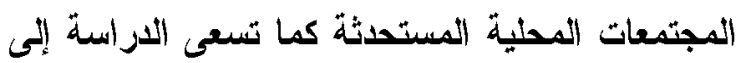
قياس فعالية العمليات التى تقوم بها الإناث من خـلال

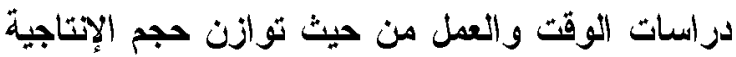
الرئيسية في عملية الإتتاج.

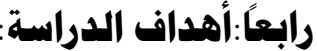

يمكن تحديد الهـف الرئيسى للاراسة فى "التعرف على التح دور الأخصائى الإجتماعى فى تنمية الوعى البيئى لاى

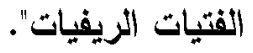

تتحدد الأهداف الفرعية للارية اسلة في التالمى: 1-تحليد دور الأخصائى الإجتماعى فى تنمية الوعى البيئى للفتيات الريفيات. r-معرفة الأثنطة التى يمارسها الأخصائى الإجتماعى لطلاب المدارس الإعدادية. r-معرفة أهمية الوعى البيئى هن وجهة نظر طـلاب التهاب المدارس الإعدادية.

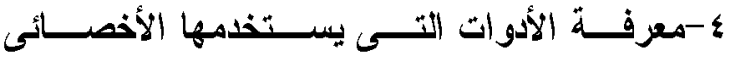
الإجتماعى لتنمية الوعى البيئى للفتيات الزيفيات.

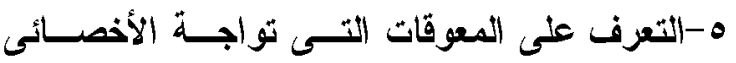
الإجتماعى فى التعامل مع المثكلات البيئة.

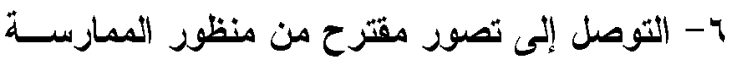

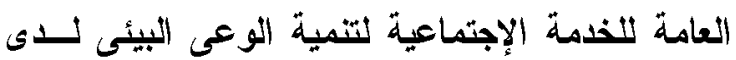
الفتيات الريفيات.

\section{خاهسًً: تساؤلات الدراسة}

يمكن صياغة تساؤلات الدراسة على النحو التالى:

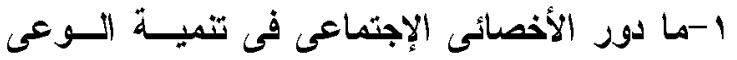
البيئى للفتيات الريفيات.؟

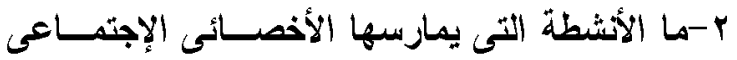

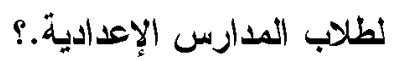

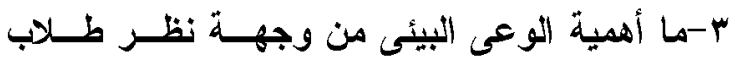

$$
\text { المدارس الإعدادية؟ }
$$

ع -ما الأدوات التّى يستخدمها الأخصائى فــى تتميــة الوعى البيئى لاى الفتيات الريفيات؟
وتأثيرها على توفير الموارد من قبل الأطفال.أعتددت

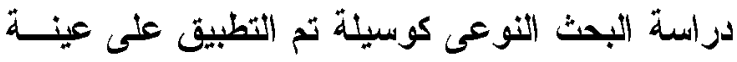

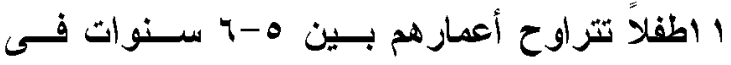
تايوان.وتوصلت إلى أن التوعية البيئية لدى الأطفــال قـ زادت إلى حد كبيز وخاصة بعد المشاهدة الفعليـة من خلال الكتب المصورة. ثانيًا:صياغة هشكلة الدراسة.

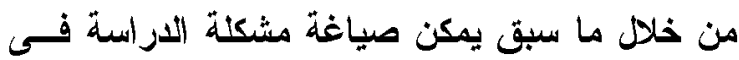

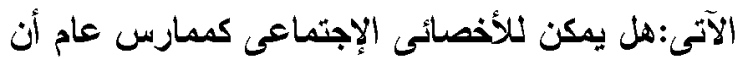
يقوم بلورة فى تنمية الوعى البيئس للفتيات الزيفيات

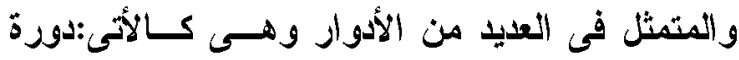
كوسيط,دورة كمعالج ,دورة كمكـن , ولورة كباحسـ ,دورة كمغير للسلوكت. ثالثًا:أهمية الدراسة تزجع أهمية الاراسة إلى أمور منها:

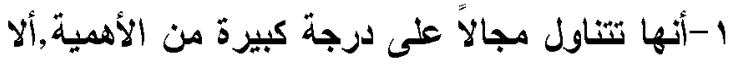

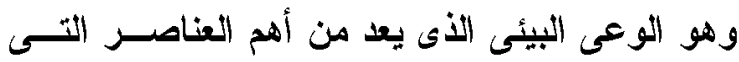

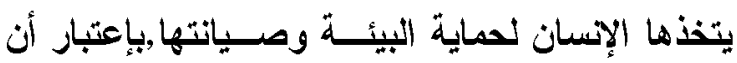
قضية البيئة قضية مجتمعية مسؤوليتها ليست حكــراً

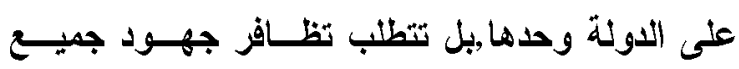

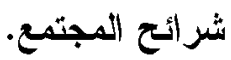
r-أهمية الدور الأى يمكن أن يضطلع بة الأخصـائى

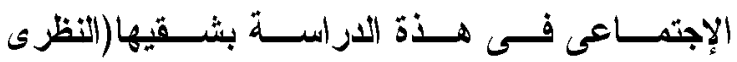

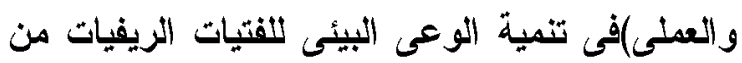

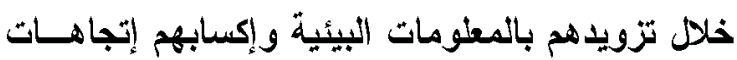
إيجابية نحو البيئة تمكنهم من درء المثكلات البئية. ب-زيادة مظاهر التصهور البيئى فى المجتمعات الريفية بسبب المشاكل البيئية الناتجة عـن تــدخل الإنسـان

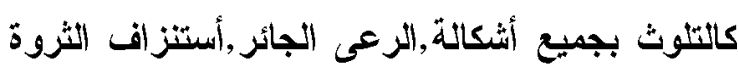

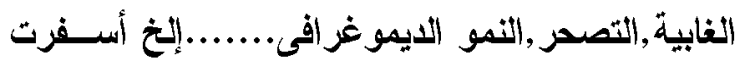

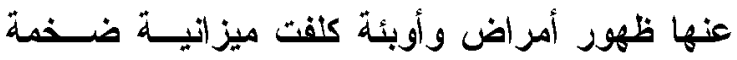
للعلاج كالتيفويد,الطاعون ,الكولير ,الرمد الحبيبى. ع-حيث أن هذة الدراسة تساهم على المسـتوى النظرث والتطبيقى فى إثراء الجهــود التـى تبــلنها 


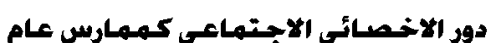

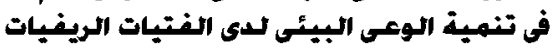

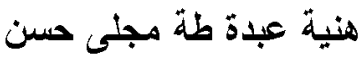

هو الحاصل على درجـة البكـالويوس فــى الخذمــة

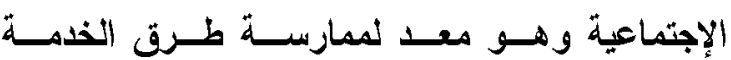

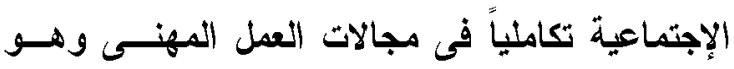

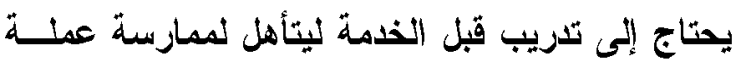

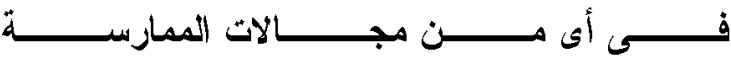
المهنية.(منقريوس ,على, 23,2000 )

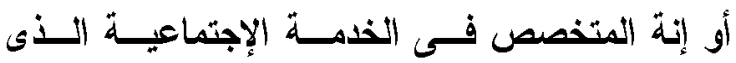
يستطيع أن يعمل مح أنساق التعامل ليقدم عديد مسن

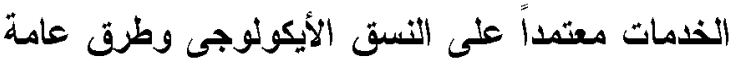

تحقيق الأهداف.(على, 11, 2010)

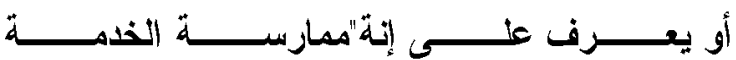

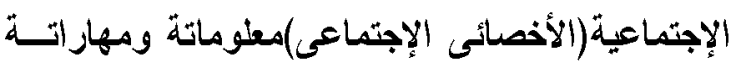
عن كل مجالات الممارسـة ويقـوم بالتقــلير العــام

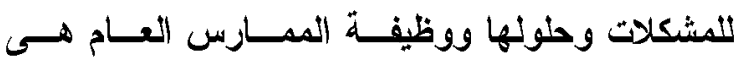
التنسيق بين جهود المتخصصين ويسهل الأتصال فيما بينه وتبنى استثرارية الزعاية حنى ينتهـ عـلاج العميل أو حل المشكلة. (محمد,35,2013 التعريف الإجر ائى للممارس العام:

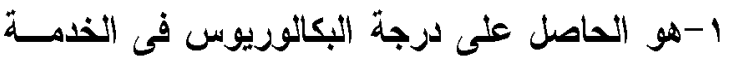

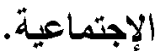
r - معد إعداداً نظرياً وعمليًا r-بمارس ضمن عملة المجال البيئى r-مفهوم تنمية الوعى البيئى: أ) تعريف التنمية: تعريف التنمية لغوياً: التنمية لغوياً جاءت من الفعل نما أق زاد ومن النماء أقى الخير والإصدلاح,ويمكن النظر إلى التنميــة بأنهـا

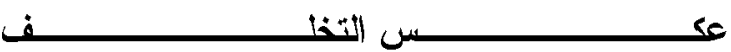
underdevelopment (أبو النصـر ,محمد,2017,

تعرف على أنها إنبثاث ونمو كل الإمكانيات والطاقــة

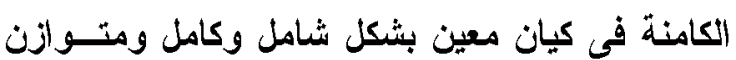

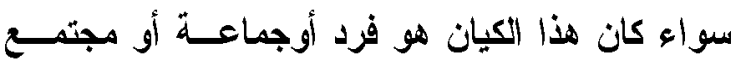
ولهزا التعريف عناصر أساسية هى: لهان 1-التنمية عملية داخلية ذاتية
צ-ما المعوقات التى تواجة الأخصائى الإجتماعى فى التعامل مع المشكلات البيئية ؟

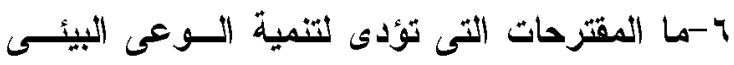
للفتيات الريفيات؟

\section{سادساً: هفاهيم الدراسة}

role: الدفهوم الدور

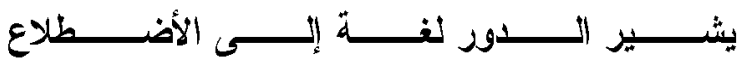

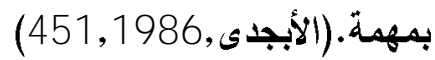
يعرف الدور بأنة مجموعة من أنماط السلوك التى التى

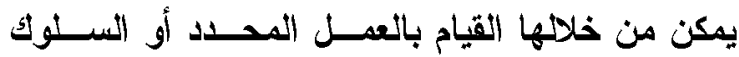

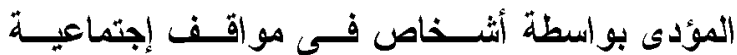
معينة. (على, 64,2009)

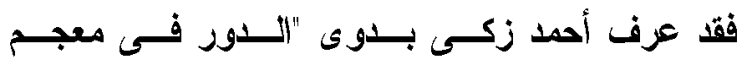

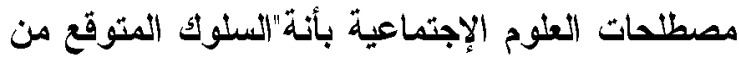

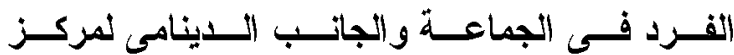
الفرد,فبينما يشير المركز إلى مكانة الفرد في الجماعة

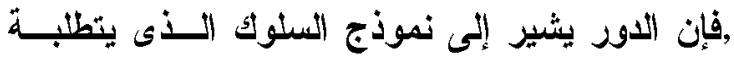

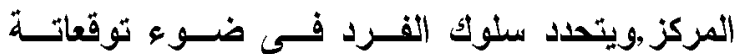

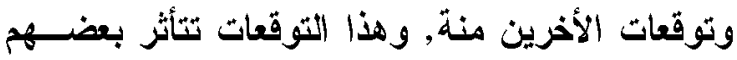

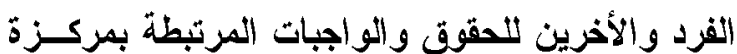

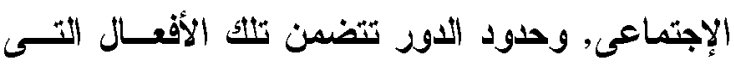

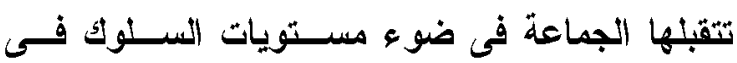
الثقافة السائدة. (بلوى, 395,1993

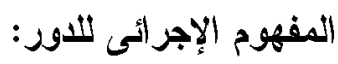

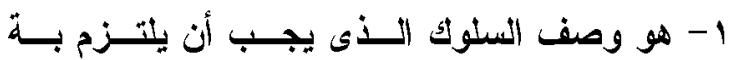

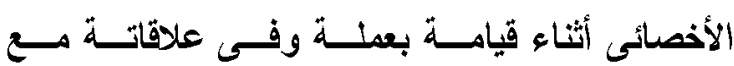

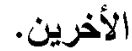

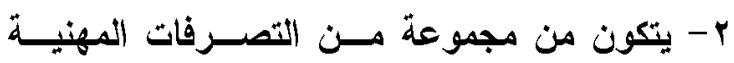
التو اعية المقصودة. بـو التى لم تستهـف منها إشباع حاجاتة هو وإنمــا إثباع حاجات الأخرين.

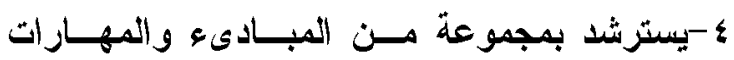
و المعارف المستمدة من العلوم الإجتماعية. ه-يسعى لتحقيق أهداف معينة. r-مفهوم الممارس العام: 


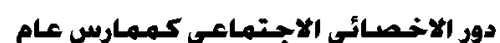

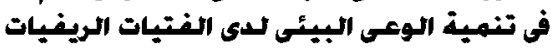

هنية عبدة طلة مجلى حسن المى لهن

هى كل ما خلقة اللة مسن الســـاء والأرض ومــا

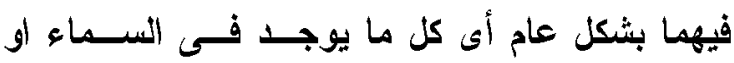

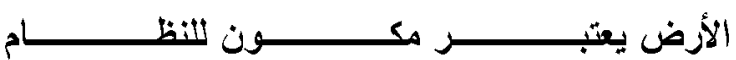

البيئي.(www.mawhopon.net)

كما يمكن تعريف البيئة في معاجم العلوم الإجتماعيــة

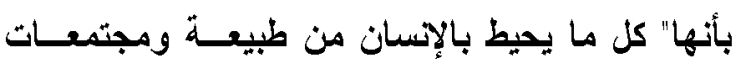

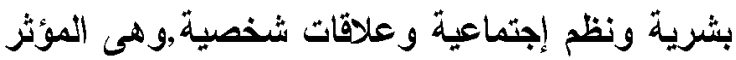

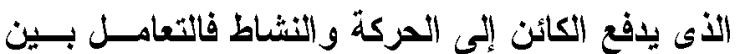
البيئة و الفرد والأخذ والعطاء مستمر ومتلاحق.

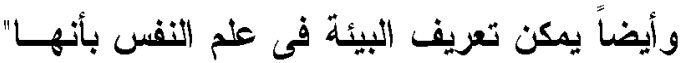
المحيط الأى يحيط بنا ويشمل الغلاف الجوى ومظاهر

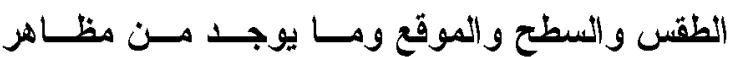
العمران ووسائل الإتتاج الزراعى والصناعى ووسائل المو اصدلاث وما إليها.(عيسوى , 14,1997 ) د-مفهوم الوعى البيئي: هو المجال الذى يعنى برفع مستوثى الــوعى البيئسى

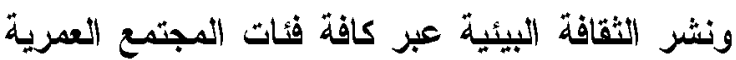
والمهنية بما يتتاسب مي عمـر الإنســان ومحيطـة

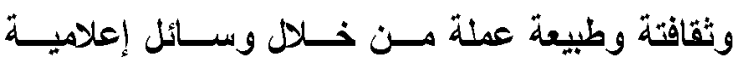
وتربوية منظمة بهدف الترويج لفكرة.(أبودية,2010,

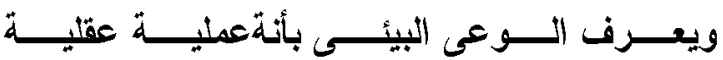
معرفية,تنظيمية يستطيع الفرد بها معرفة الأثياء في الثئي هويتها الملائمة.(السنهورى, 31,1990 )

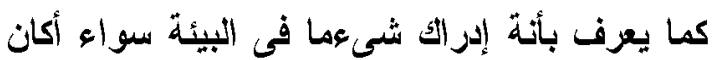

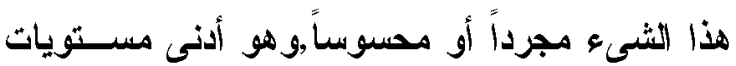
المجال الوجداني.(مبروكت, (38,2000)

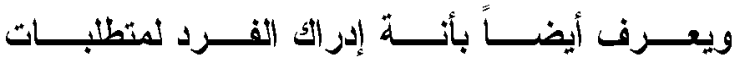

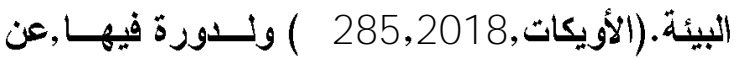
طريق إحساسة ومعرفتة بمكوناتها ورما بينهمــا مسنـ

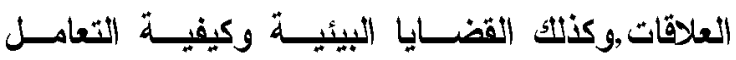

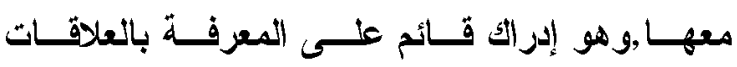

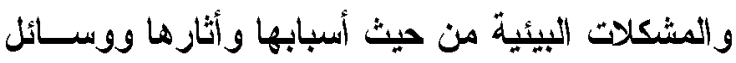

حلها.(المقدادى, 180,2016 ) r-التنمية عملية ديناميكية ذاتية

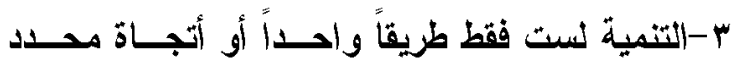

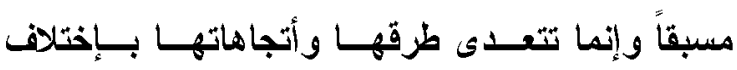

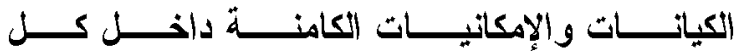
كيان.(أبوطاحونة, 216,1997 )

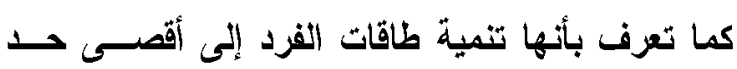

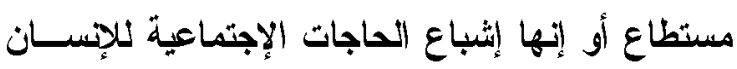
أو الوصرل بالفرد لمستوثى معين من المعيثة, أو أنها عملية توافق إجتماعى. (أبوكريشة,2003, 37)

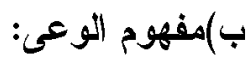

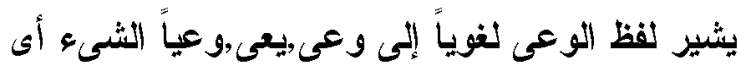

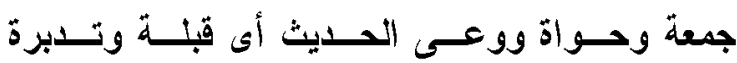

وحفظة. (فتيحة, 85,2012 ) مفهوم الوعى أصطلاحاً: هو حالة من الإدرالك الذي يجمع بين تفعيل دور العقل والمثاعر لفهم ما يدور حول الإنسان ,ولتنظيم

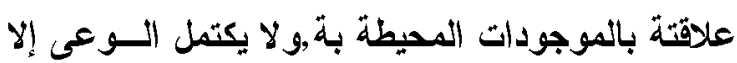
إذا عمل الإسسان على تنميتها بثكل مسنمر من خلا

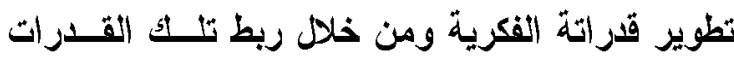

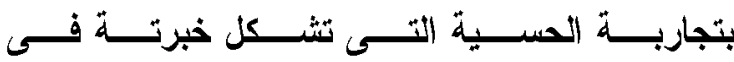
(https://www.ida2at.com)(الحياة) ج)مهوم البيئة: تعريف البيئة لغوياً:

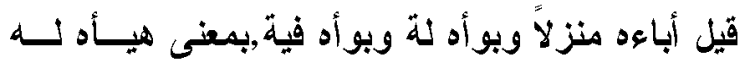

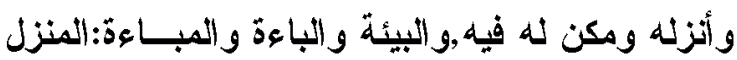

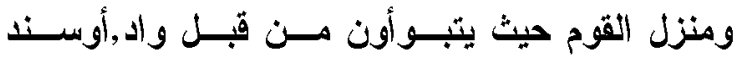

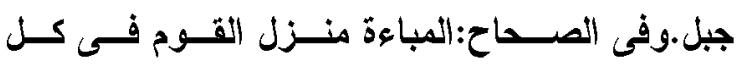

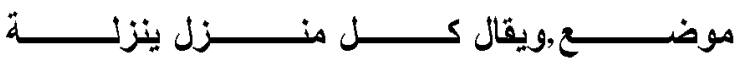
القوم.(بورزق, 34,2009) مفهوم البيئة أصطلاحاً:

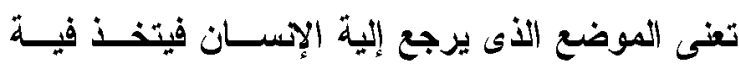

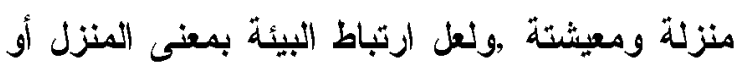

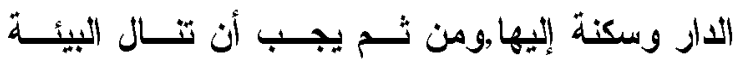

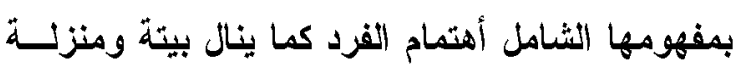
أهتمامة وحرصة.(عبد العال الايربي, 15,2016 ) 


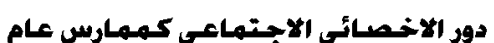

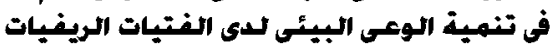

هنية عبدة طلة مجلى حسن المى لهن

وعلاقات تقوم الدول بالألتزام بها فى إطارها الإقليمى و الاولى. (النجاب, 2017)

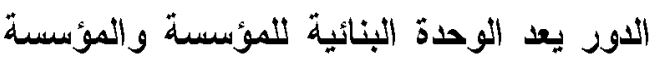

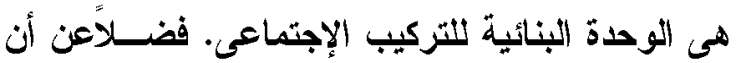

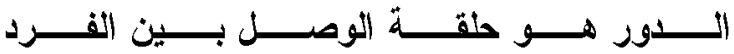

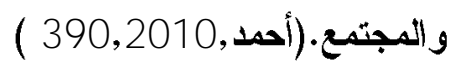

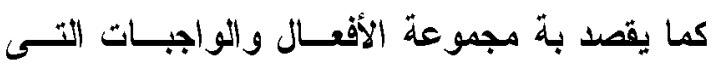

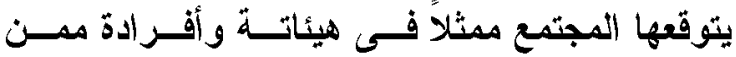

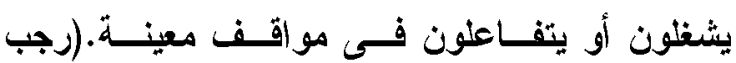
) أخرون, (37,1983 )

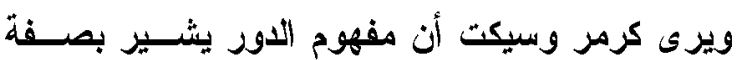

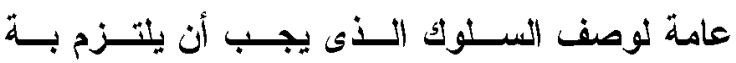
الأخصائى الإجتماعى أنثاء ثيامة بعملة روفى علاقاتة

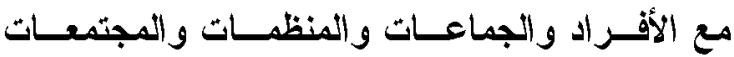
المحية.(المليجى, 153,2001 ) مدى الأستفادة من هذة النظرية:

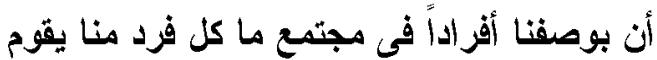

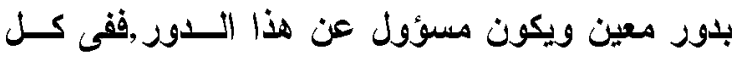

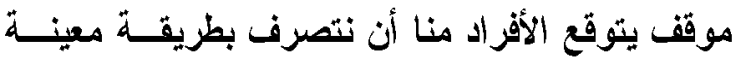

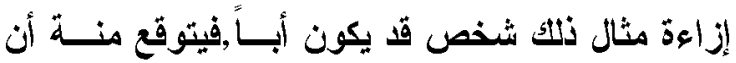
يتصرف وفق سلوكيات معينة تناسـبـ دورة الأبسـوى

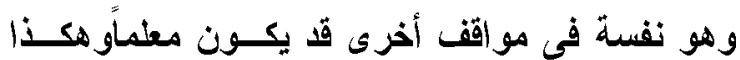

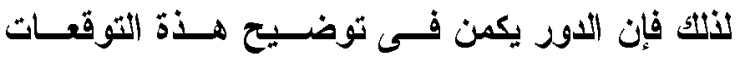

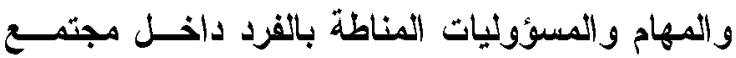
ما.ووفقاً لنظرية الاور الإجتماعى ,ققدوزعت الأعمال

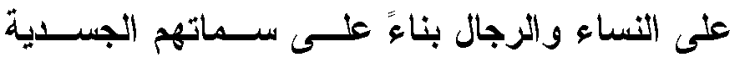

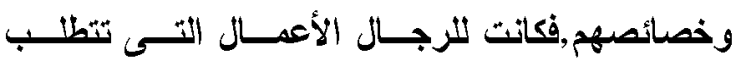

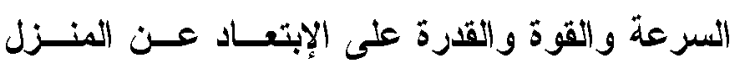

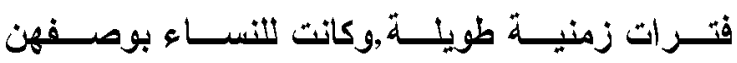
المسؤولات عن الإجاب الأعمال التى تتطلب البقاء في زمئ

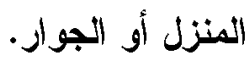
(determinism):ب-نظرية الحتمية البيئية ويطلق عليها المدرسة البيئية وهى تؤمن بأن الإسسان

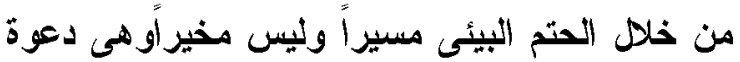
قديمة قدم الفكر الجغرافى ومن أبرز روادها الأقدمين
ويرث البعض أن الوعى البيئى هو الإدرالك القائم على

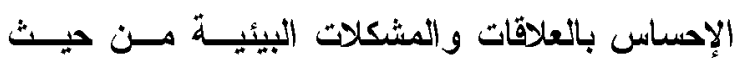

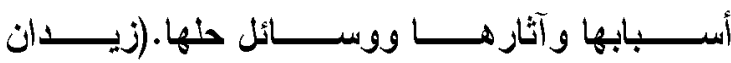
وآخرون, 622,2006). تنمية الوعى البيئى: ونمان تعزف بأنها جه تعليمى موجة ومقصود نحو التعرف وتكوين المدركات لفهم العلاقات المعقدة بين الإنســان

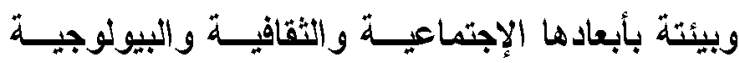

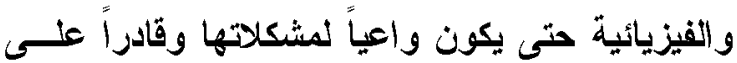

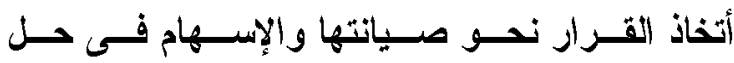

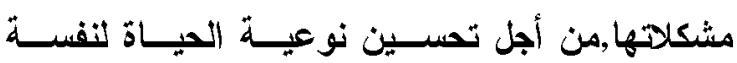

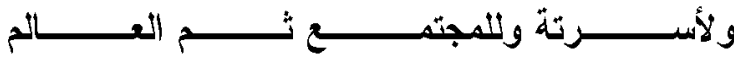
كلة.(الاسوقى, 85,2017 مرجع سبق ذكرة) التعريف الإجرائى التتمية الوعى البيئى:

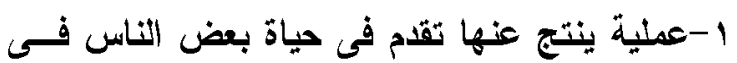
بيئة معينة. r بوأكتساب معلومات وخبرات عن البيئة ومشكلاتها.

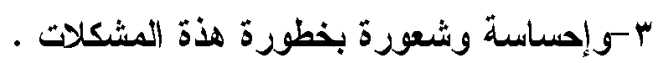

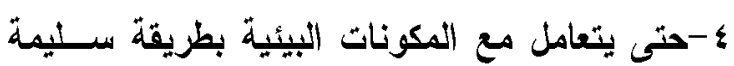
وإيبانية. هو المثاركة في المشكلات البيئية و العمل على حلها لمنع حدوثها مرة أخرى. ه-مفهوم الفتيات الريفيات:

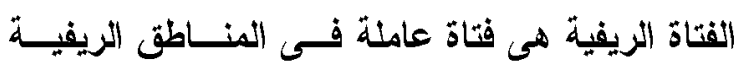

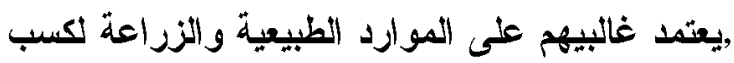

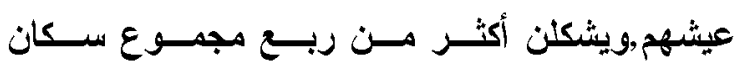
العالم.(https://ar.m.wikipedia.org) التعريف الإجرائى للفتاة الريفية: 1-هى الفتاة التى تخرج من المنزل للعمل. r-تعل فى رقعة الأرض الزراعية. r-مقابل أجر نقدى متفق علية.

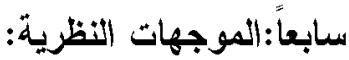
ا-نظرية الاور : أن نظرية الدور تقوم في الأسـاس النساس على وجود تفاعلات وتوجهات ونشـاطات ورغبـات 


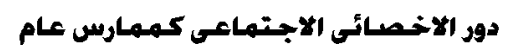

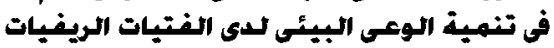

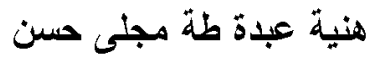

الإسـانية والقرارات الفردية والظـروف الإجتماعيـة عملياً أى تأثير على التنمية الثقافية.

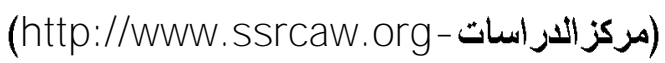

ملى الأستفادة من نظرية الحتمية البيئية:

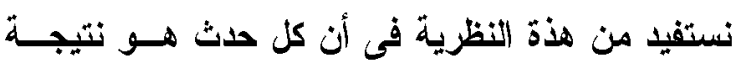

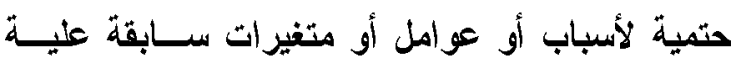

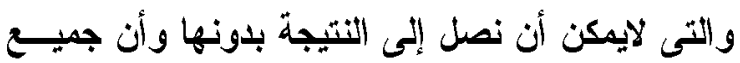
الحوادث في الطبيعة تجرث وفقاً لقوانين الطبيعة ذاتها

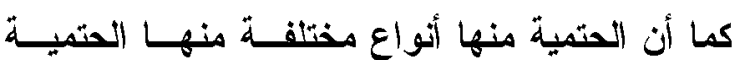

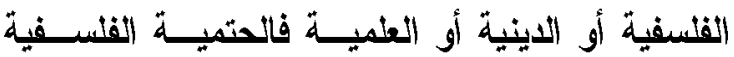
تستتا على النظرية السببية الكلية.

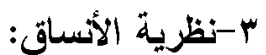

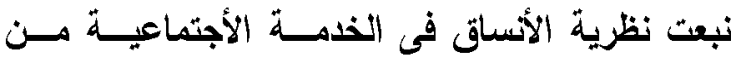
النظرية العامة للأساق وهى نظرية بيولوجية أسسها

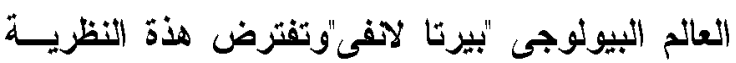

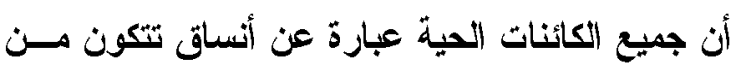

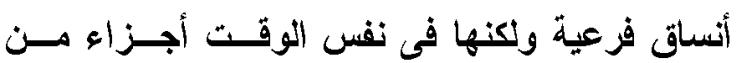

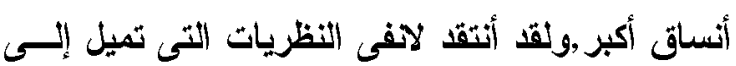

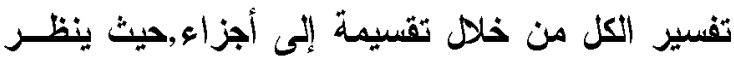
إلى النسق ككل متكامل فى إطار التفاعلات المتبادلـــة

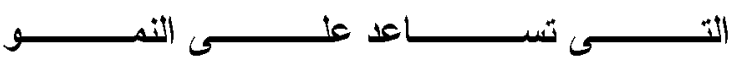
و التغيير •(سليمان, 46,2005).

مختلف الأسساق ,فهى تؤكد على العلاقات بين الأقراد

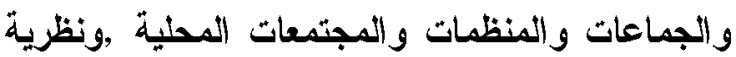

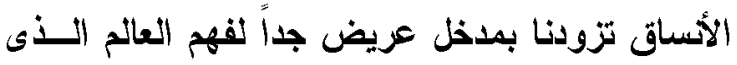

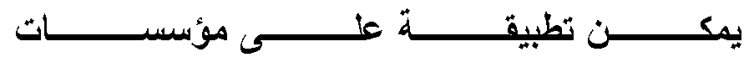
متعددة. (السنهورى ,230,2007). أ-مفهوم النسث الإجتماعى: غالباً ما يستخدم مفهوم النست الإجتماعى بشكل غئن الإهير

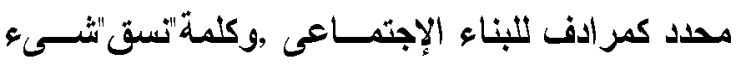
يتصف بأنة مركب,أو مجموعة من الأثنياء أو الأجزاء

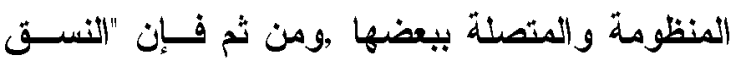
الإجتماعى"يدل على الصلات الاخلية المستقزة بـينين

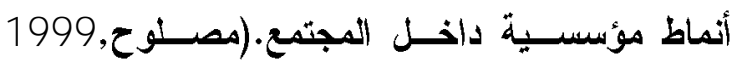
.671,
هيبرقز اط,أرسطو اللان ربط بين المنــاخح وطبـائع

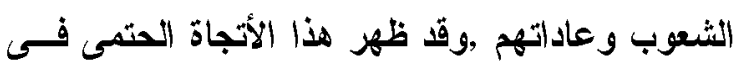

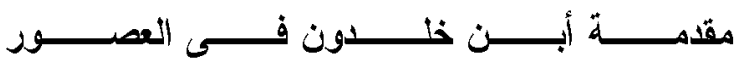
الوسطى. (أحمد, 128,2015 ) ومثال على ذلت تأثير البيئة على عظام الإســان فإِإنا

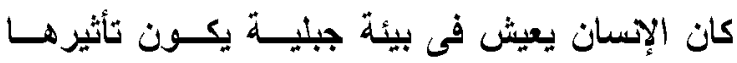

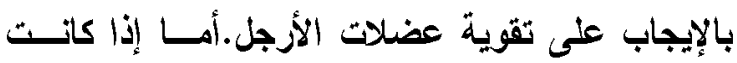

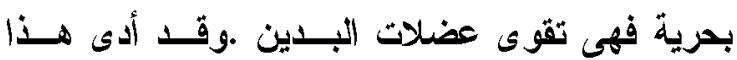

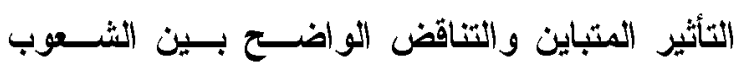

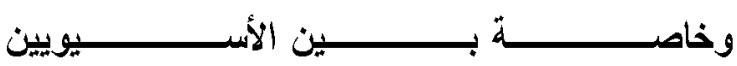

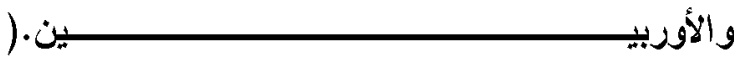
index. php<www. lawoflibya.com/forum/ (archi السبب الأساسى بظهور هذة النظرية هـــ التيــاقض

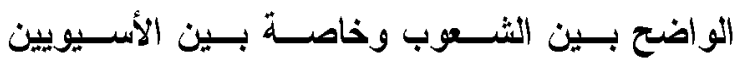

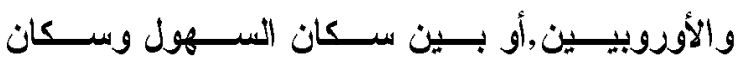

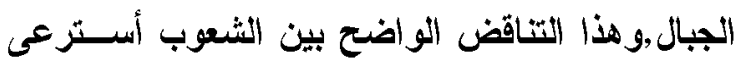

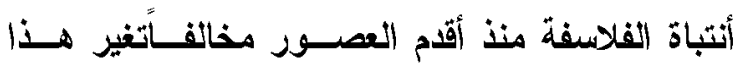
التناقض بإختلاف البيئات الطبيعية التى يعـيش فــ ظلها الإسان. (عفيفى,أحمد, 23, 1996 )

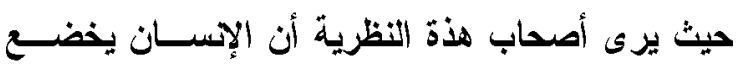
بكل ما فية للبيئة فهى التى تسيطر علية وليس العكس

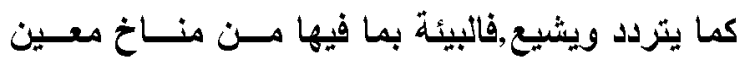

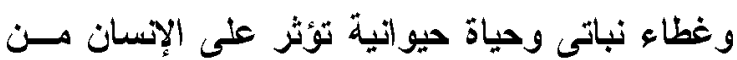
مختلف الجوانب. (https://www.startimes.com) مثال:المناخ والغطاء التباتى والحياة الحيوانية تحسدد نشاط الإنسان وعلاقاتة التجارية

(blo. . <www. prepschool. blogspot.com)

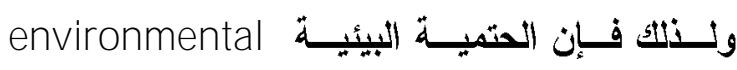
determinism هي الإعتقاد بـأن البئـــة (وأبــرز

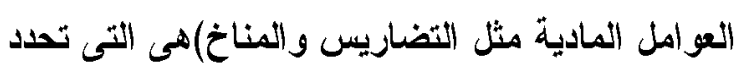

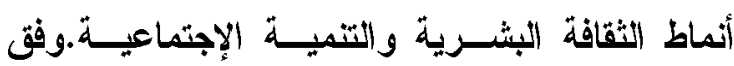

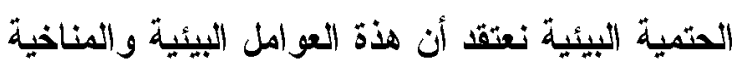

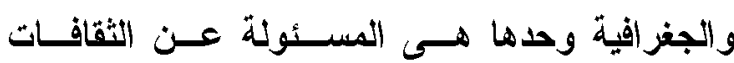




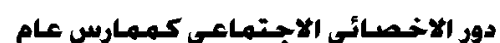

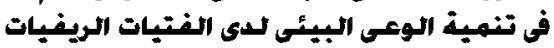

هنية عبدة طلة مجلى حسن المى لهن

ويشمل الأخصائى الإجتماعى والمؤسسة وفريق العمل

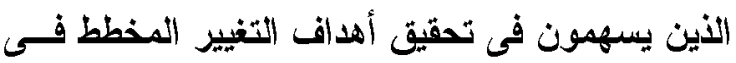

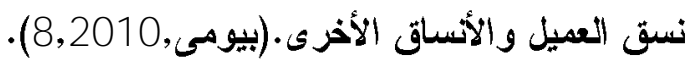
ج-نسق العمل:

ويثنمل الأخصائى الإجتماعى محدث التغييـر

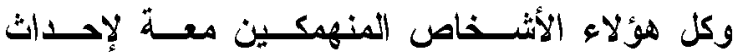
التغييز ,أى هؤلاء الناس الأين يعمل معهم ومن خلاهه

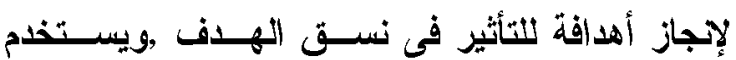
مصطلح نسق العمل أو الفعل ليصف هــؤلاء الـــين يتعامل معهم الأخصائى الإجتماعى من خلال جهــودة

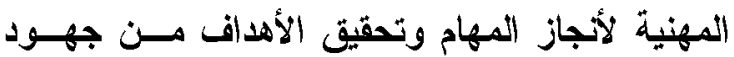
التغيير ,ورغم أن جهود تركز تجاة نسق الهـدف فأفان

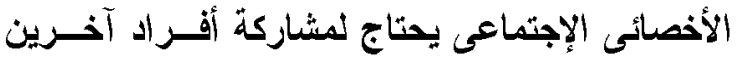

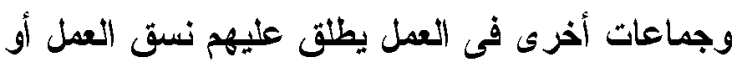

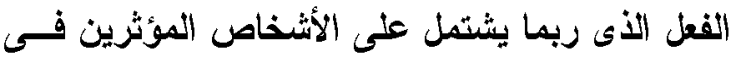
نسق العميل مثل الأسرة,أو الجماعات التى يسـنطيع

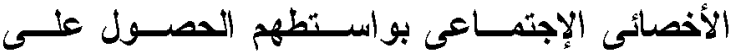

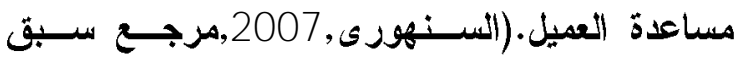

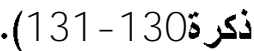

د-نسق الهُف أو نسق المستهذف: نسق الهُف هو النسث الأى توجة نحسوة عمليـات المساعدة المهنية,بهذف إحداث التغيير فية بمعنى أنة هو النسق الأى توجة نحوة جهود التخل المهنى التى

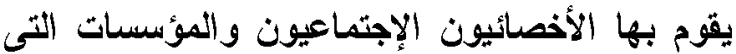

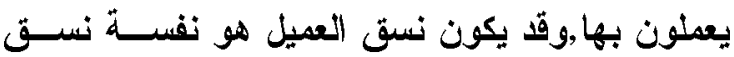
الهُف.(أبو النصر ,41,2009 -42). جوز جائف النسث الإجتماعى:

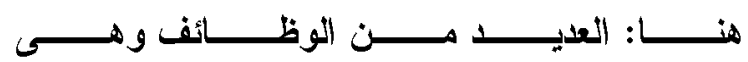
كالتالى:(يمانى, 153,2020 أستحقيق هدف النسق:تزتيب أولويات الأهداف وحشد الموارد الداخلية و الخارجية لتحقيقها. ب-التكيف:وتهتم بعلاقات النست مع البيئة الخارجيــة

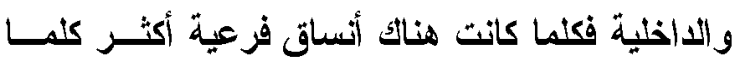
كانت العملية التكيفية أصعب تعقيداً. ج -صيانة النمط:الحفاظ على أستمرار النسق. نعيد.
ب-أنساق الممارسة المهنية فى الخدمة الإجتماعية: 1-النسث المسئول عن إحداث التغييز :يعتبر الأخصائى الإجتماعى مغيراً إجتماعياً لما لة من أدوار عليدة فئ عملية إحداث التغيير المطلوب في جميع عناصر مهنة الخدمة الإجتماعية.

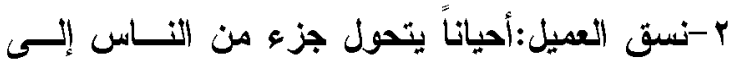
عملاء,وذلت عذدما يطلبون الخدمة من الأخصـائيين الإجتماعيين. r-نسق الهُف أو النسق المستهوف:هو النسق الأى

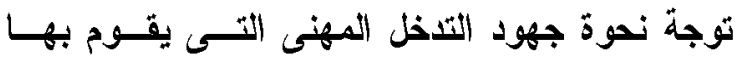

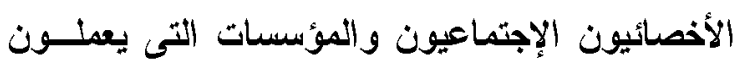

؛-نسق الفعل أو العمل:يتضمن نسق الفعل في مهنة الخدمة الإجتماعية مجموعة من المكونــات هـــئأ-

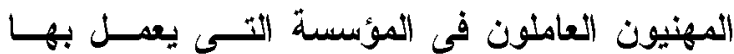
الأخصائى الإجتماعى.

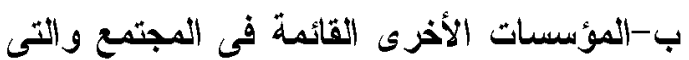

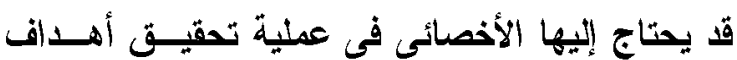

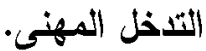
ه-النسق المهنى:يتضمن النسق المهنى في الخدمسة الأجتماعية مجموعة من المكونات هي: أ-المنظمات المهنية الخاصة بالخدمة الإجتماعية مثل هن النقابة ومجلس مدارس الخدمة الإجتماعية. ب-التسث التعليمى الخــاص بالخدمــة الإجتماعيــة

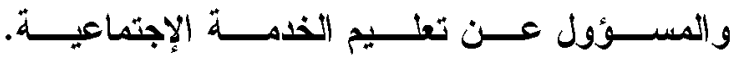
(https://sport- mania.net) أنساق التعامل في إطار الممارسدة العامة: أ-نسق العميل: ويتمثل فى العميل كفرد عندما يتعامل معة الأخصـائى العيلى

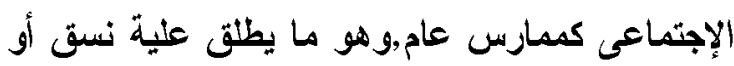

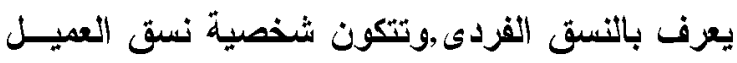

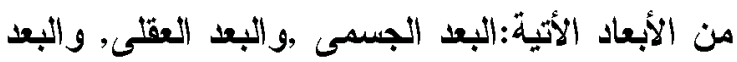
الإجتماعى ,و البعد النفسى.(على, 19,2009). ب-نست التغيير: 


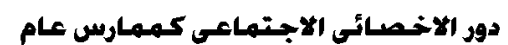

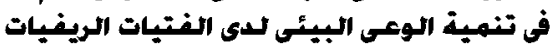

هنية عبدة طلة مجلى حسن المى لهن

مصطلح أيكولوجى يأنى من النظريات البيولوجية

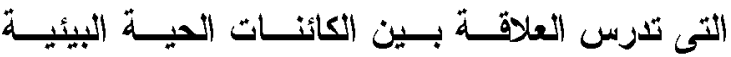

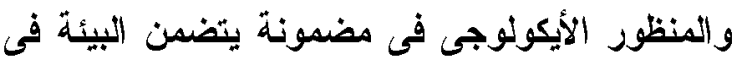
عليات التغيير ويحصر مناطق وحدودتنمية الإنسـان وتغيير الإسان حيث ان يتضمن البيئة بثكل واسع . (iouise,c\&Stephen,2001) ويعنى مصــطح النظــام الإيكونــوجى العناصــر

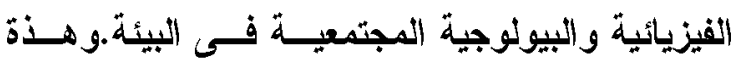
الكائنات نثكل مجموعة معقدة من العلاقةــات وتعــلـل

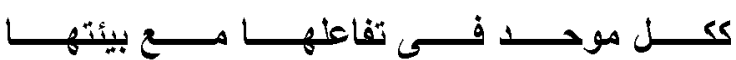

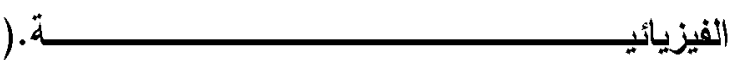
https://www. who.int/gobalchange/ecos

مدى الأستفادة من المنظور الأيكولوجى: يوجة المنظوز الأيكولوجى الممارس العام عند التعامل ميع الفتيات الريفيـات ومثــكلاتهم بضــرورة فهـ علاقاته الشخصية بالبيئة التى يعيثون فيها وكما أن هذا المنظور يضع نماذج محدة للممارسة العامة مما لهابل

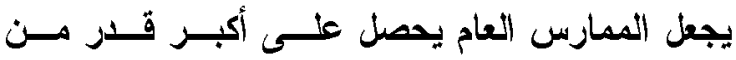

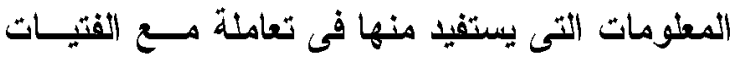

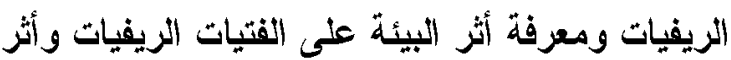

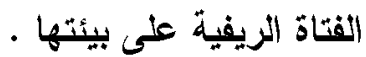

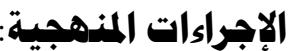
أولاً:نوع الدراسة: تنتمى هذة الدراسة إلى أحد أنواع الأراسات العلميـة

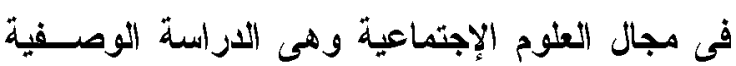

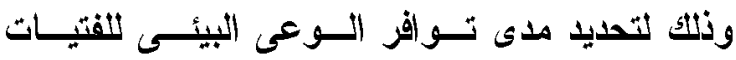

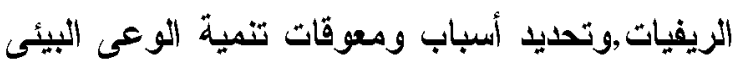

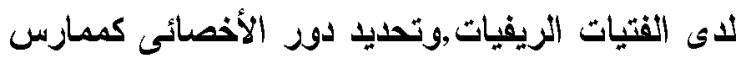

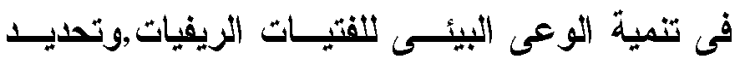

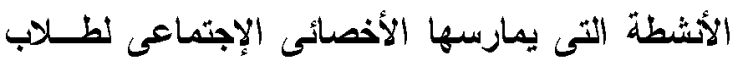

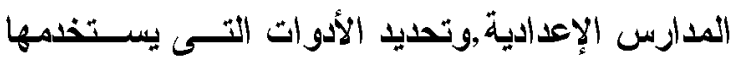

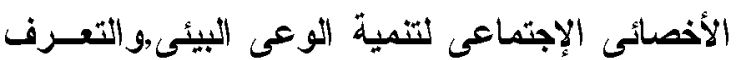

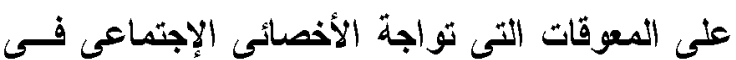

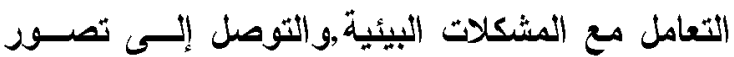

د-التكامل:ويعتمد على ثلافة قواعـــ هـى التســاند

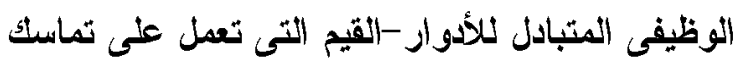
التسق -التمركز حول أهدافة. د-خصائص الأنساق العامة :

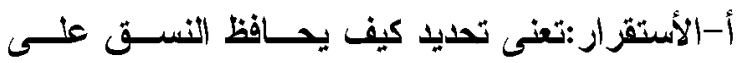
وجودة من خلال حصولة على المــدخلات و المــوارد

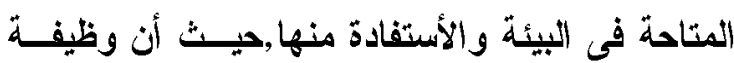
التسثق يعتمد على أستمرار تدفق الموارد من البئيسة

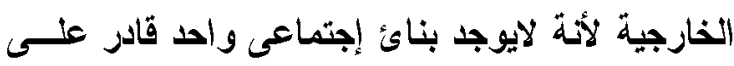
الأكتفاء ذاتياً دون الأعنماد على البيئة الخارجية. ب-التوازن:تثثير إلى قدرة النسث على الحفاظ عـى الحس

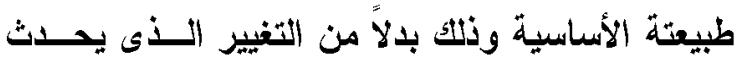
للنست نتيجة لتلقى المدخلات.

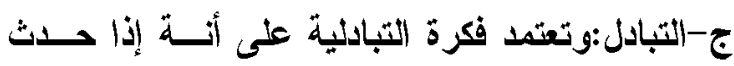

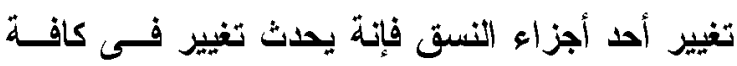
أجزاء النسق الأخرى.(خليل, 143,2009). د-مدخل المعلومات:حيث إن الأنساق المفترحة تشمل الاحل

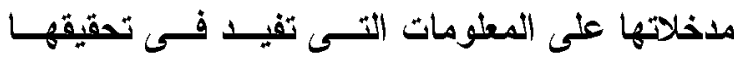
لأهدافها ووإن المعلومات السلبية عن إنجازاتها يفيد

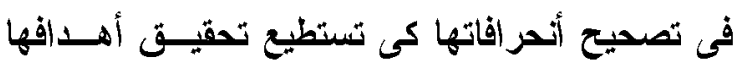
المنثودة. (عبد اللطيف, 335,2000 -336). مدى الأستفادة من نظرية الأساق:

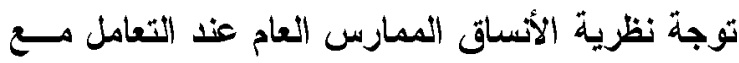
الفتيات الزيفيات إلى أخذ الأنسات الأخرى في الأعتبار

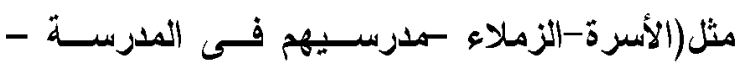

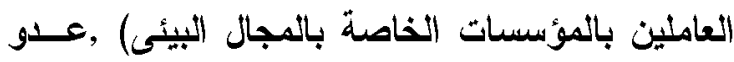

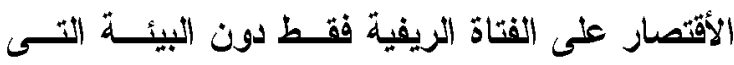

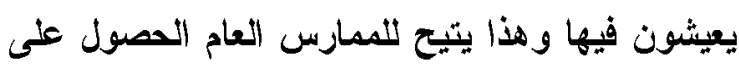

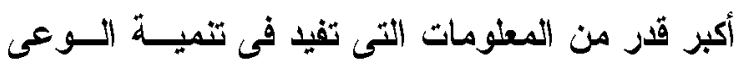

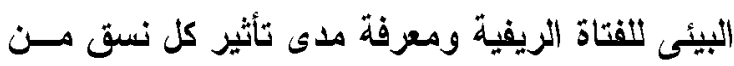
هذة الأسساق فى تنمية الوعى البيئى للفتيات الريفيات

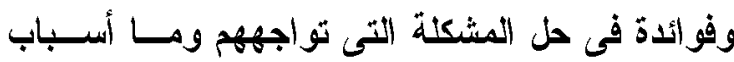

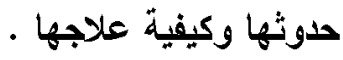

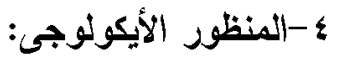




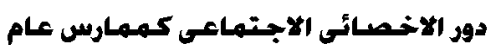

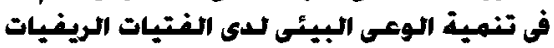

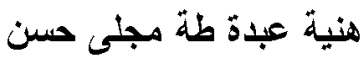

حيث قامت الباحثة بتصميم استمارة أستبيان للفتيـات

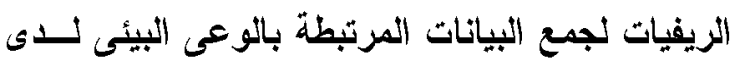

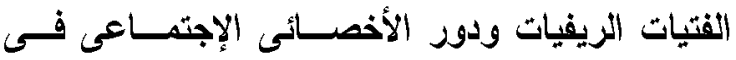
تنميتة .

وقد اتبعت الباحثة عدة مراحل لتصميم هذة الأستمارة وهى : أ- المرحلة التمهيدية:

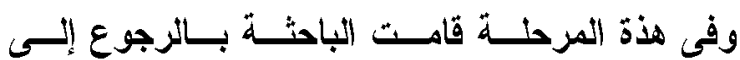

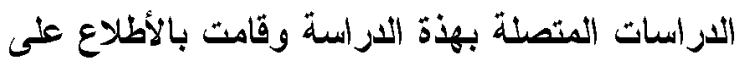
الأستمارات والمقاييس المتعلقة بتنمية الوعى البئسمى

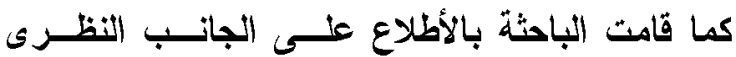

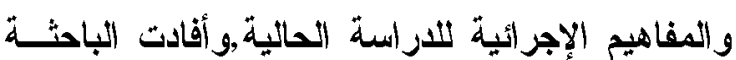
منها فى العصول على بعـض المتغيـرات المتصــلة بموضوع الار اسة.

ب-مرحلة صياغة أسئلة الأستمارة المبائية:

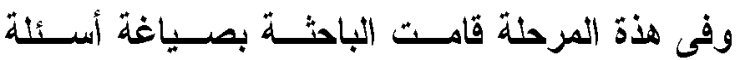
الاستمارة في صورتها المبلئية: وقد تم مر اعاة الآتى: - أن تثنتمل كل عبارة على فكرة واحدة.

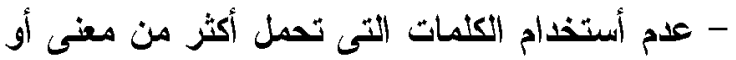
تكرار عبار ات تحمل نفس المضمون. ج-موازين التقبير: أحترت الأستمارة على بعض الأسئلة التى تطلبــــ أن

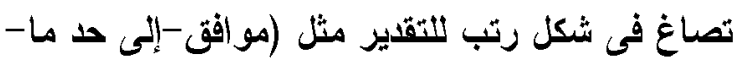
غير موافق) وقد تم إعطاء هذة الرتب الأوزان الآتية:

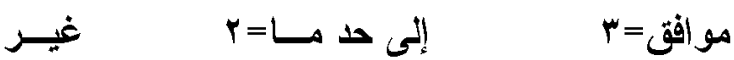
مو أثقى

د-مرحلة التأكد من صدق الأستثمارة:

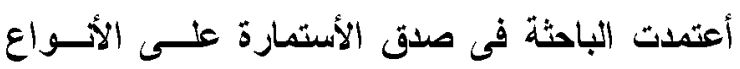
الآتية من الصدق:

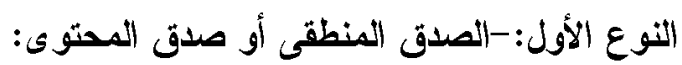
وفى هذا النوع من الصدق قامت الباحثة بالآتى:

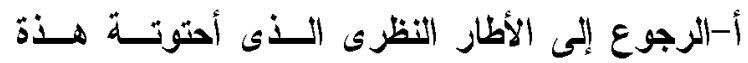

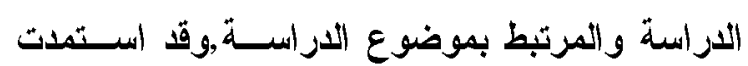

مقترح من منظور الممارسة العامة للخدمة الإجتماعية تتنمية الوعى البيئى لـدى الفتيـات الريفيـات.(على $(38,2014$,

ثانياً:المنهج المستخدم: تم الأعتماد على منهج المسح

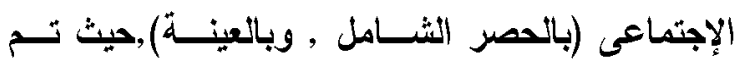
أستخدام المسح الإجتماعى الشامل لجميع الأخصائيين

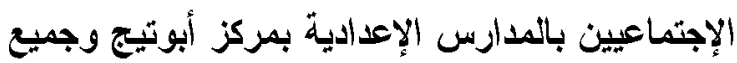

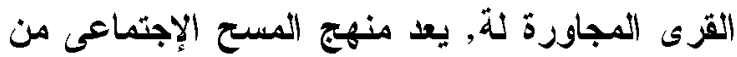

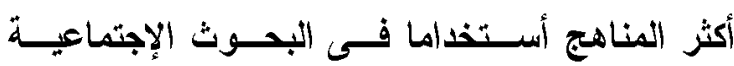

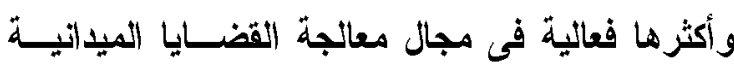
حيث يعتمد هذا المنهج على تحليل وجمع المعلومسـات

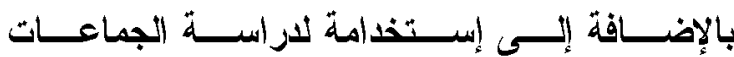
و المنظمات. (عبدالرحن,

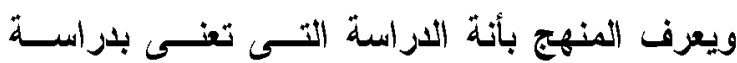

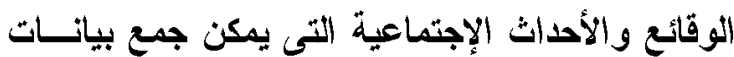
كمية عنها لتثمل مختلف القضايا الأسرية والتعليمية

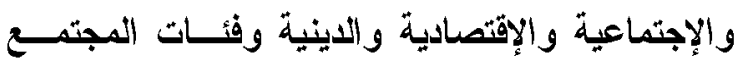
وطبقاتة بهدف تقديم معثومات يمكن الأستفادة بها فى والأي

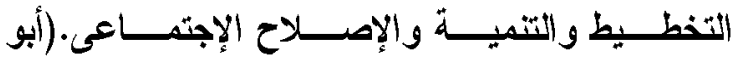
النصر , 140,2017) كما تم أستخدام منهج المسح الإجتماعى بالعينة وذلتك بأختيار (r امدرسة من بين المدارس)

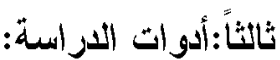
أعتمدت الاراسة الحالية على استمارة أستبيان ,وذلتص

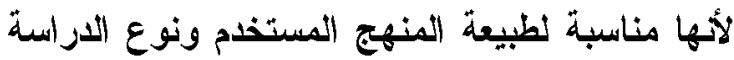

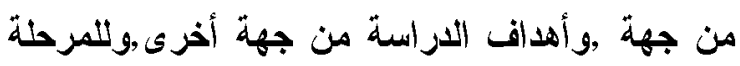
العمرية لعينة البحث. وتتمثل الأداة في الأتى: العينه

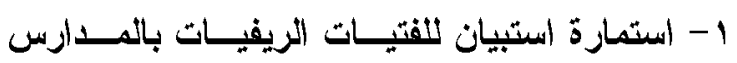
الأعدادية بمركز أبوتيج.

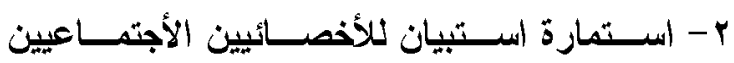
بالمدارس الأعدادية بمركز أبوتيج.

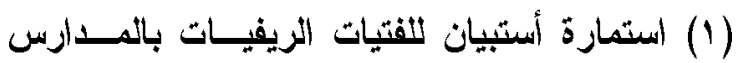
الأعدادية بمركز أبوتيج. 


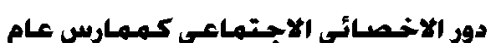

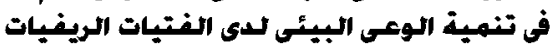

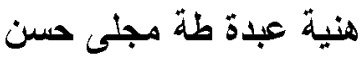

^-البيانات الخاصة بالمقترحات التى تؤدى إلى تنمية اللوعى البيئ للفتيات الزيفيات. النوع الثالث:الصدق الذانى (الصدق الإحصائى):

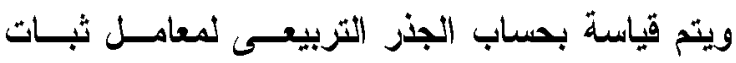

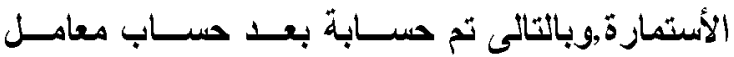
الثبات. ه-مرطلة التأكد من ثبات الأستمارة:

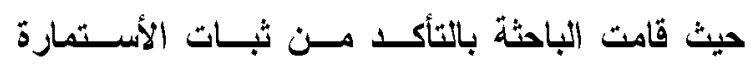

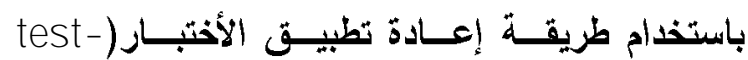

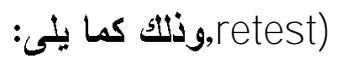

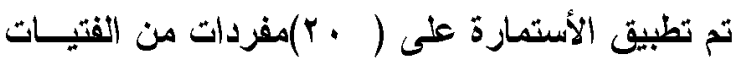

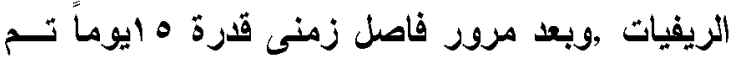

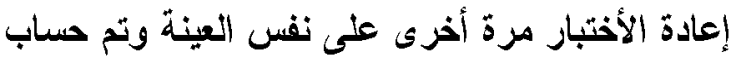

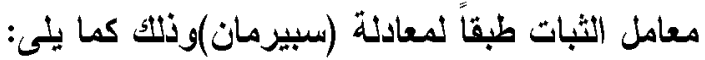

$$
\frac{1=(\jmath)}{(1-r)(j)}-1=
$$

وأصبحت نتيجة ثبات استمارة الفتيات الريفيات 9 هر, . وأن الصدق الأحصائى

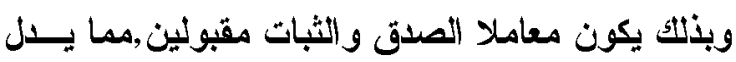
على صدق الأستمارة وثباتها.

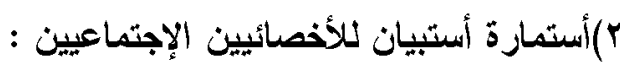

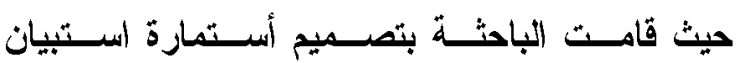
للأخصائيين الإجتماعيين بالمدارس الإعدادية بمركـز أبوتيج وقراه وذلاتك لجمع البيانات مسن الأخصـائيين

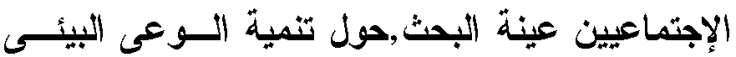

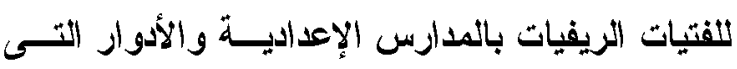

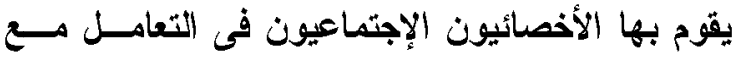

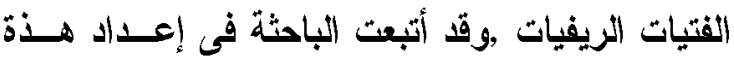
الأستمارة الخطوات الأثية :

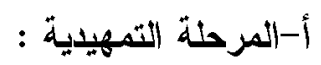

وقا أتبعت الباحثة الخطوات التى أتبعتها فــ إعـــاد إستمارة الأستبيان الخاصة بالفتيات الريفيات. ب-مرحلة صياغة أسئلة الأستمارة المبلئية:
المجلة العلمية للخدمة الاجتماعية

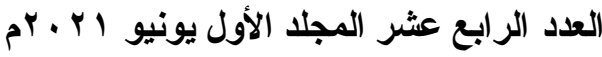

الباحثة من ذلت المعلومات التى ساعدتها في صـياغة عبار ات الأستمارة. ب-الاطلاع على عدد من الثراسات المتعلقة بالفتيات

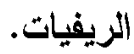
النوع الثانى :-الصدق الظاهرى:

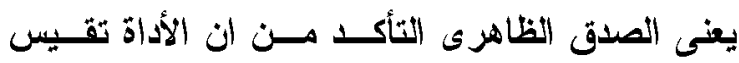

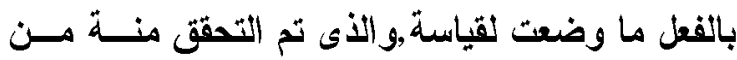

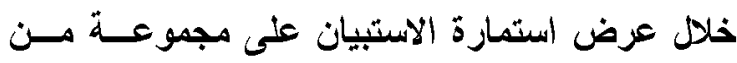

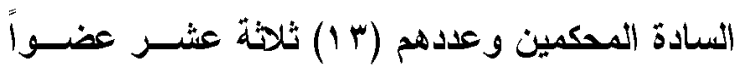
من أعضاء هيئة التدريس بكلية الخدمة الاجتماعيـة فئة

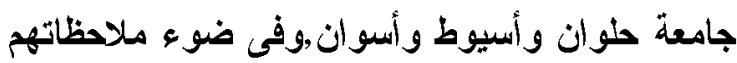

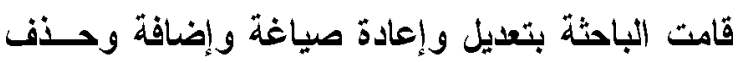

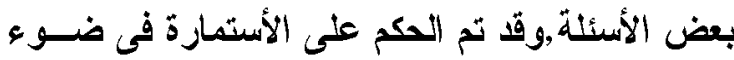
عدة معايير هى : بهن أ- مدى سلامة الصياغة للعبارة ووضوحها. ب - مدى ارتباط العبارة بالبعد الذى تقيسة.

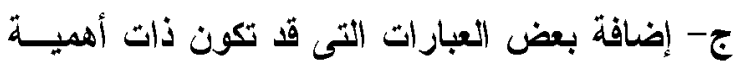
من وجهة نظر المحكم. وخرجت الاستمارة فى صورتها النهائية مشتملة على

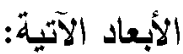
1-البيانات الأولية. ب-البيانات الخاصة بأدوار الأخصائيى الإجتماعى فـى الأهـ تنمية الوعى البيئى للفتيات الزيفيات. باديات الاهديات

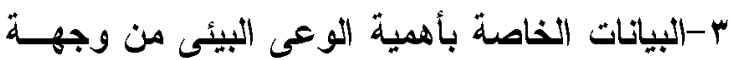
نظر الفتيات الريفيات. ؟-البيانات الخاصة بالأشطة الخاصــة بالأخصــائى الإجتماعى التى يمارسها طلاب المدارس الإعدادية.

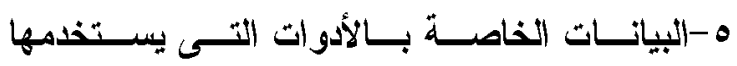

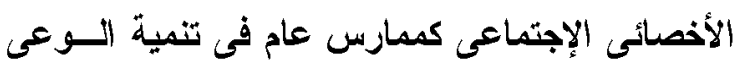
البيئى للفتيات الريفيات.

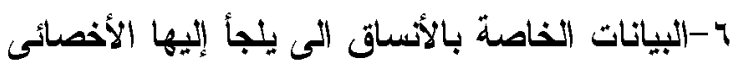
الإجتماعى عند تعاملة مع مشكلات الفتيات الريفيات.

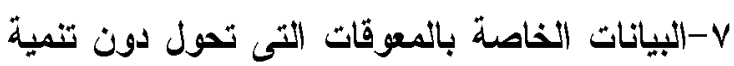

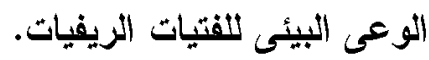




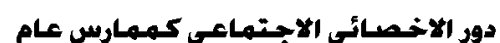

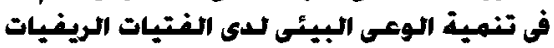

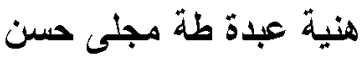

؛-البيانات الخاصة بالمعوقات التى تواجة الأخصائى

الإجتماعى عند التعامل مـع الفتيات الريفيات.

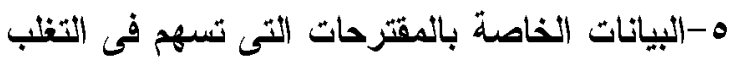

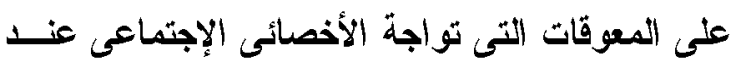

التعامل مي الفتيات الريفيات.

ه-مرحلة التأكد من ثبات الأستمارة:

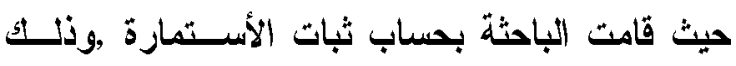

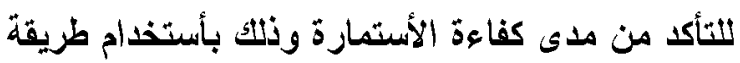

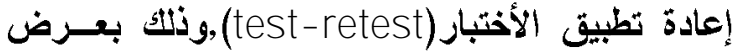
الأستمارة على (· · (1)من الأخصـائيين الإجتمــاعيين

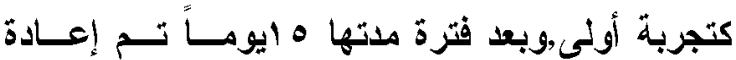
تطبيق الأختبار على نفس العينة ,وتم حساب معامـلـ الثبات طبقاً لمعادلة سبير مان.

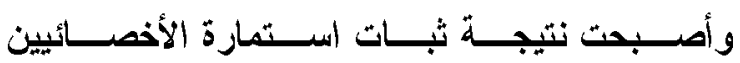

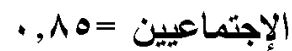

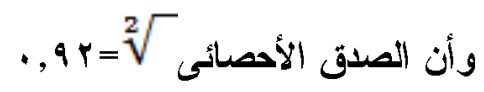

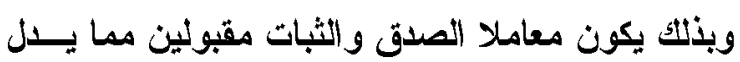

على صدق الأستمارة وثباتها رابعاً:مجالات الار اسلة: 1-المجال البشرى:ويتمثل في الآتى:
المجلة العلمية للخدمة الاجتماعية

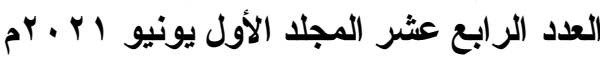

وفى هذة المرحلة قامست الباحثــة بصــياغة أســئة الأستمارة فى صورتها المبدئية. ج-موازين التقاير: وهى نفس الإجراءات المتبعة فى الأستمارة الأولى. د-مرحلة التأكد من صدق الأستمارة: حيث أعتمدت الباحثة فى إجزاء صدق الأستمارة على الاسئمارة

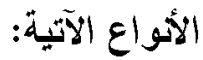
النوع الأول:الصدق المنطقى أو صدق المحتو: المتوى:

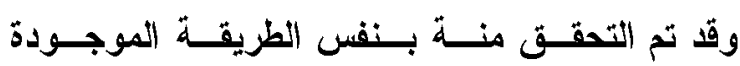

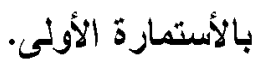
النوع الثانى:الصدق الظاهرى:

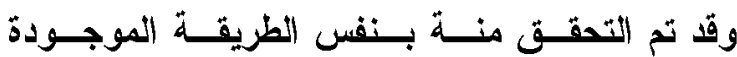

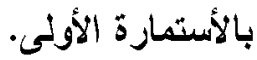
وقد خرجت الأستمارة في صورتها النهائية مشــنملة على العبار ات الآتية: 1-البيانات الأولية. r-البيانات الخاصة بلور الأخصائى الإجتماعى عـــــ التعامل مي الفتيات الريفيات.

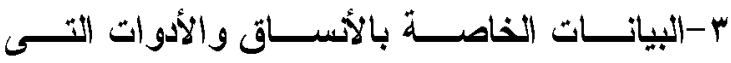

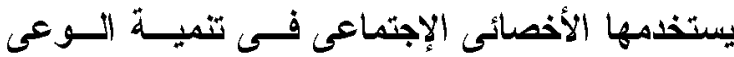
البيئى لاى الفتيات الريفيات.

- العصر الثامل للأخصائيين الأجتماعيين العاملين بالمدارس الإعدادية بمركز أبوتيج وقزاة وعددهم 9 ؛أخصائى

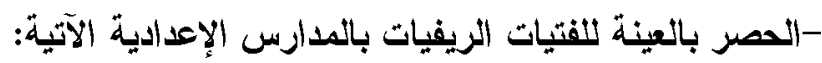

\begin{tabular}{|c|c|}
\hline العدد المد & اسم المدرسة \\
\hline 10 & دكران الإعدادية المشتركة \\
\hline iv & المسعودى الإعدادية المشتركة \\
\hline 11 & البلايزة الإعدادية المثتزكة \\
\hline 10 & الزيزة الإعدادية المشتركة \\
\hline$r$. & أبوخرص الإعدادية المشتركة \\
\hline $1 \varepsilon$ & عمر بن الخطاب دوينة الإعدادية المشتركة \\
\hline r. & السفير جاد الحق بنى سميع الإعدادية المشتركة \\
\hline 10 & دير ريفا الإعدادية المشتركة \\
\hline$r \cdot$ & فاطمة الزهراء الإعدادية بنات بأبوتيج \\
\hline$r$. & الإعدادية الحيثة بأبوتيج \\
\hline
\end{tabular}




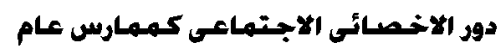

\begin{tabular}{|c|c|}
\hline 10 & فاطمة الزهر اء الإعدادية بنات بالنخيلة \\
\hline 19 & أبو الحارث الإعدادية المشتركة \\
\hline
\end{tabular}

1- يوجث بة عدد كبير من المدارس الإعدادية

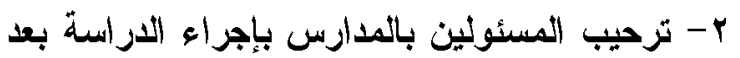
أن ثامت الباحثة بالحصول على الموافقات الرسـمية المختلفة.

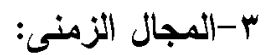
تم تطبيق الادراسة فى الفترة الزمنية من rV نــــوفمبر

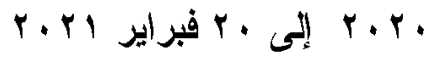
خامساً:الأساليب الأحصــائية المســتخدمة فــى هـــة

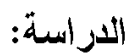
اعتمدت الدراسة على عدد من الأساليب الإحصــائية

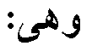

وقد تم اختيار هذة المدارس للمبررات الآتية: 1- يوجد بها مجموعة الخدمة العامة مسن الفتيـات الريفيات ويوجد بعدد صغير بسبب ظروف المدارس.

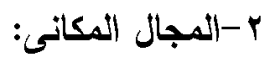

تم تطبيق الدراسة الميدانية على المـــارس الأثيــة مدرسة دكران الإعدادية المثتركة-مدرسة المسعودى

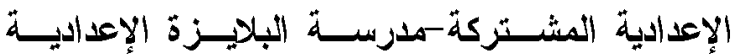

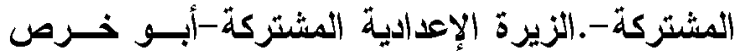
الإعدادية المثتركة-عمربن الخطاب دوينة الإعداديـة المشتركة-السفيز جاد الحق بنـــ ســيع الإعداديـة الإنة المشتركة-دير ريفا الإعداديـة المشـتركة-فاطدـة الزهراء الإعدادية بنات بأبوتيج),وقد تم أختيار مركز أبوتيج بقراه للمبررات الأتية:

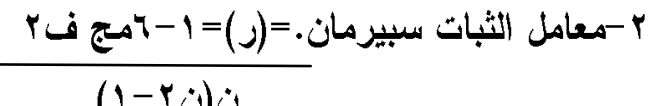
ن(1-r)

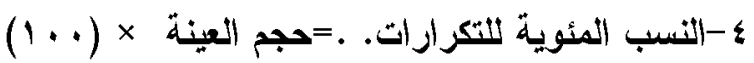

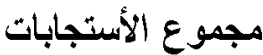

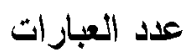

مجموع الأوزان

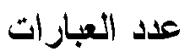

مجموع الأوزان

V-حساب المنتوسط المرجح =

عدد العينة

مجموع الأوزان لكل العبارات

$1 \ldots \times$ 1-حساب القوة النسبية= r-جاءت نتائج أدوار الأخصـائى الإجتمـاعى فـى

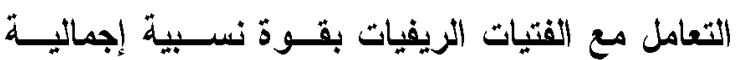

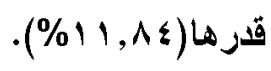

\section{نتائج الدراسة:}

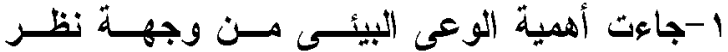

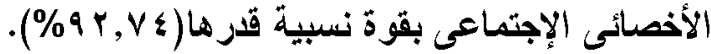




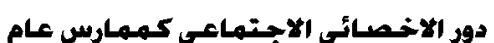

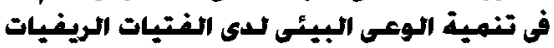

هنية عبدة طة مجلى حسن

^- توفير التمويل اللازم للادوات والمعدات الخاصــة

بالهيئات التعليمية.

9- تعليل الأتجاهات السلبية لاثى الفتيــات الريفيـات

تجاة البيئة.

• 1 - الأهنمام بالجانب التطبيقى الخاص بمجال

التوعية البيئية.
المجلة العلمية للخدمة الاجتماعية

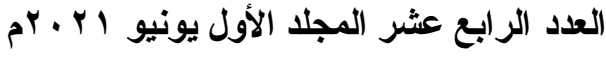

r-جاءت نتائج الارسة الخاصة بالألساق بقوة نسبية قدرها)

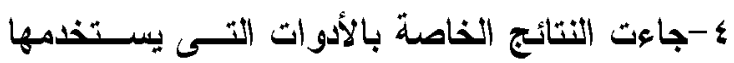

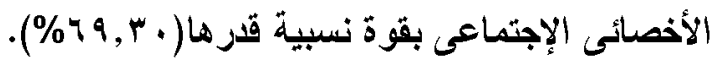

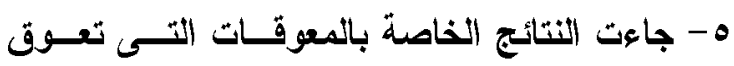
الأخصائى الإجتماعى عند التعامل ميع الفتيات الريفيات

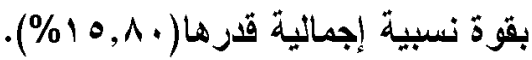

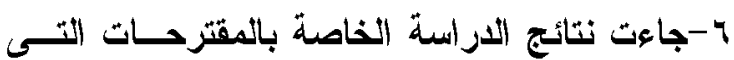

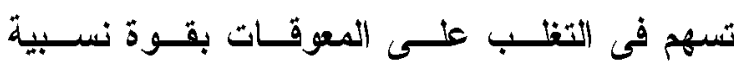

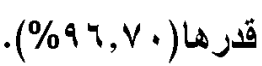

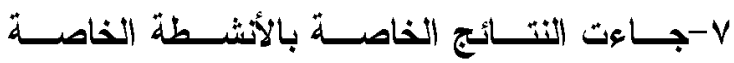

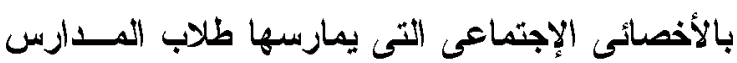

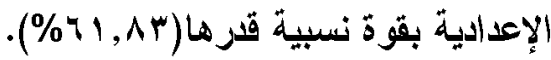

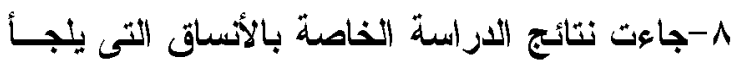

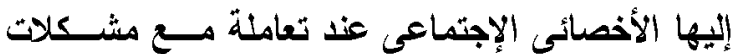

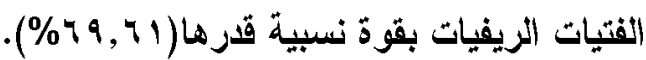
9- جاءت نتائج الدراسة الخاصة بالمعوقـات التــى تحول دون تنمية الوعى البيئى للفتيات الريفيات بقوة باته

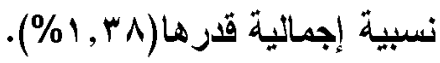
• ا-جاءت نتائج الدراسة الخاصة بالمقترحات التهى

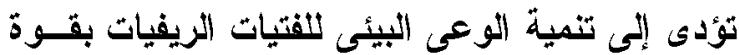

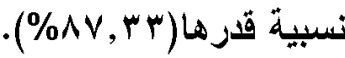

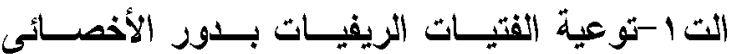
الإجتماعى من خلال عقد لقاءات معهم. ب-القيام بدورات تدريبية للأخصائيين الإجتماعيين. ب-توفير الإمكانيات البشرية والمادية التى تساعد فى لإنه تنمية الوعى البيئى للفتيات الريفيات.

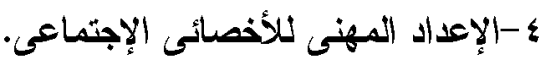

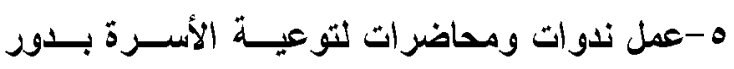
الأخصائى الإجتماعى فى تنمية الوعى البيئى للفتيـات الريفيات.

צ- تنظيم ندوات لتوعية الفتيات الريفيـات بالمجـال البيأي. V- تحقيق التوازن بين الموارد المتاحة وعدد الفتيات الزيفيات الملتحقين بالتعليم. 


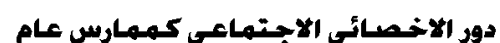

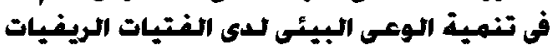
هنية عبدة طة مجلى حسن

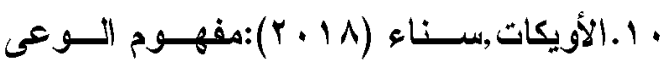

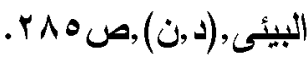

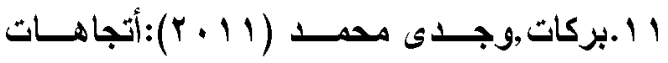

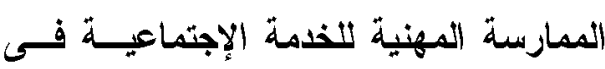

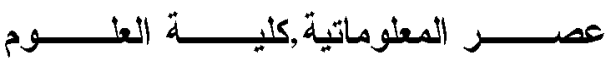
الإجتماعية, (د,ن) ,جامعة أم القزى.

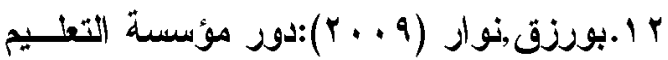

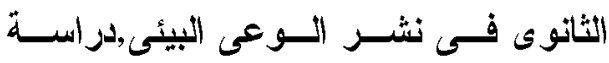
مبدانية بثانوية مصطفى بن بوالعبد بالثريعة

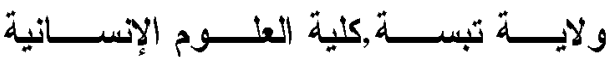
و الإجتماعية,جامعة منتورى -قسنطينة,مذكرة مكملة لنيل شهادة الماجستير فى علم إجتماع

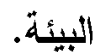

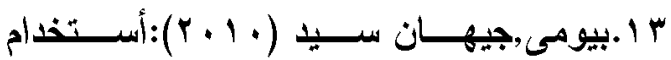

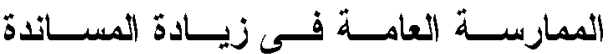
الإجتماعية لدى أمهات ضعاف العقول رمجلة دراسات فى الخذمــة الإجتماعيـة والعــوم الإسـانية,العدد الثامن و العثرون,ج الركليـة الخدمة الإجتماعية ,جامعة حوان.

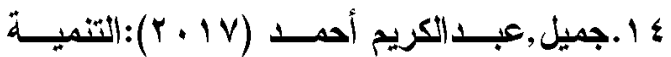

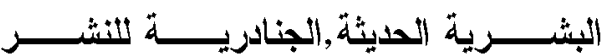
و التمزيع,عمان.

1 ا.حجاب,محمد منير (999 199):التوث وحماية البيئية ,قضايا البيئة من منظور إبــلاهى,دار

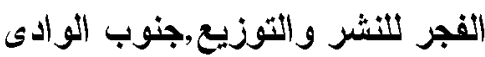

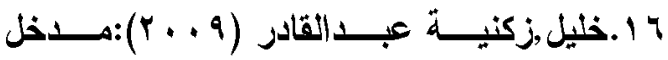
الممارسة العامسة فــ مجــالات الخدمسة الاجتماعية,مكتبة الأجلو المصرية,القاهرة.

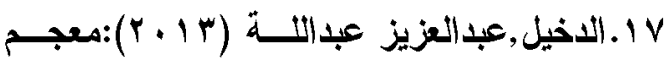
مصطلحات الخدمة الإجتماعية,دار المنــاهج للنثر و التوزيع,جامعة الملثك سعود.

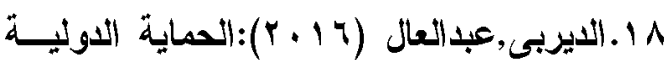

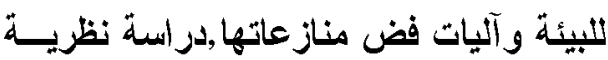
تطبيقيةهع إثثارة خاصة إلى دور المحكمـة
قائمة المراجع

أولاً:المراجع العربية:

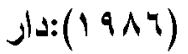

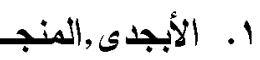

$$
\text { المشرق ,(د,ن),بيروت. }
$$

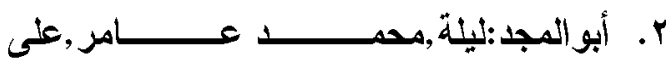

(994 (99):دور الخدمة الإجتماعية فى حماية البيئة,دار المعرفة الجامعية,الأزاريطة.

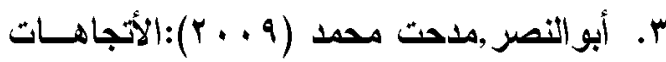
المعاصرة في ممارسة الخدمة الإجتماعيـة الوقائية,مجموعة النيل العربية,القاهرة.

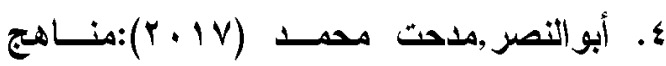

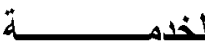

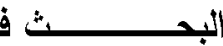

الإجتماعية, (د,ن),المجموعة العربية للتذريب و والنثر.

ه. أبو النصر :محد,مدحت محمدرياسمين مدحت

sustainable التنمية المستدامة مفهومها, أبعادهــــ development

$$
\text { مؤثر اتها, (د,ن) . }
$$

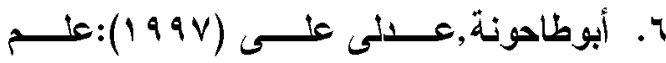
الإجتماع الريفى,المدخل والمفــاهيم أندـاط التغير للمشكلات كلية الزراعة,المنوفية

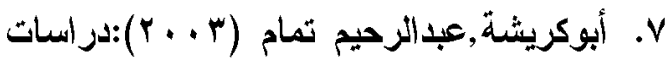

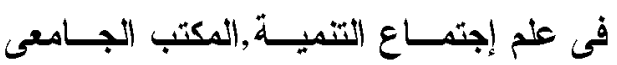

$$
\text { الحليث, الإسكندرية }
$$

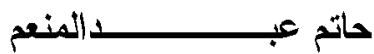

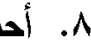

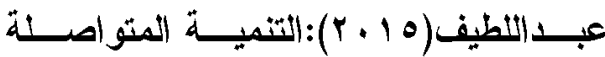

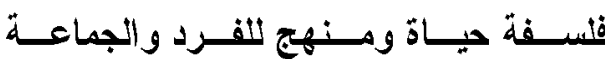

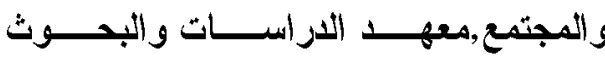
البيئية,بورصة الكتب للنشر والتوزيعربئرامعة عين شسس, القاهرة.

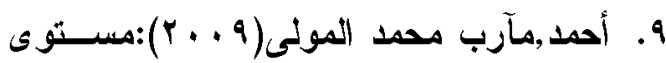

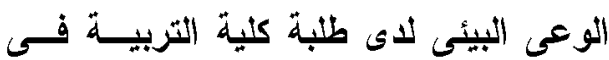

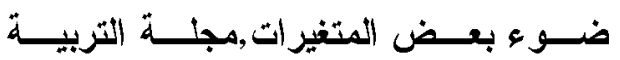
و العلم, جامعة الموصل, المجلد، 1 ,العددץ. 


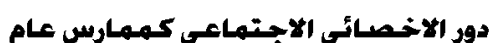

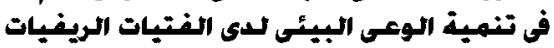

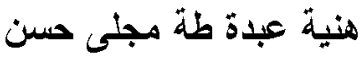

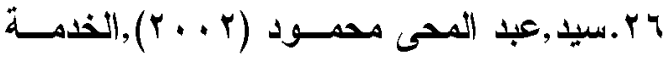

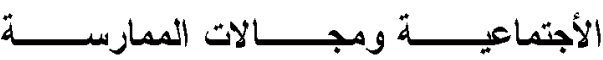

المهنية,المعهد العالى للخدمسة الإجتماعيـة

بالأسكندرية,دار المعرفة الجامعية

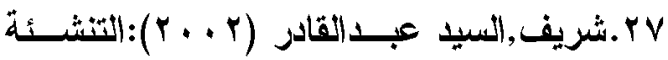

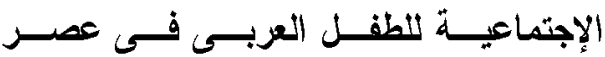

العولمة,دلار الفكر العربي,القاهزة.

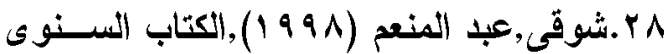

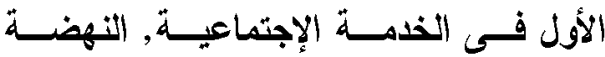

المصرية,كلية الأداب ,جامعة المنيا

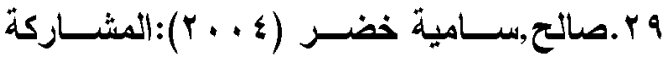

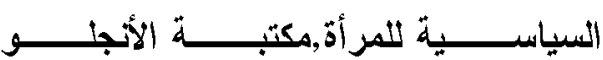

المصرية, القاهزة.

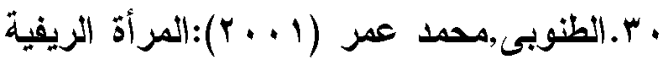

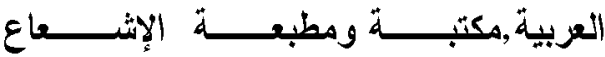

القنية,الإسكندرية

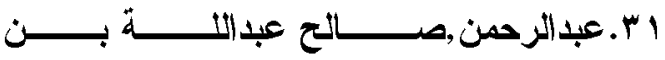

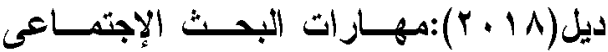
وتقنياتة, الرياض, ,العبيكان.

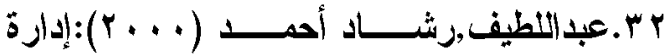

وتنميــة المؤسســـات الإجتـاعية,المكتبــة

الجامعية,الإسكندرية.

rr.عطية:بدوى, العيد عبدالحميد ,هناء حـافظ

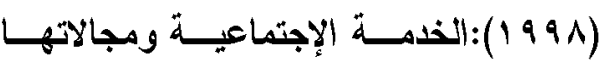

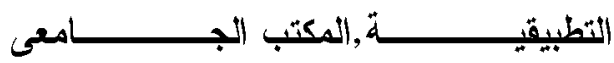

الحديث, الإسكندرية.

ع r.عفيفى:أحمد,عبد الكريم,حاتم عبــد المــنم

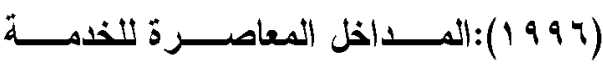

الإجتماعية في مجال البيئة,القاهرة

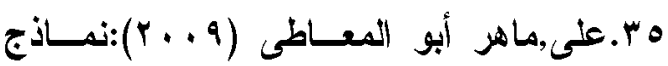

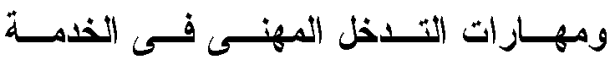

الإجنماعية,مكتبة الزهز اء,القاهزة.

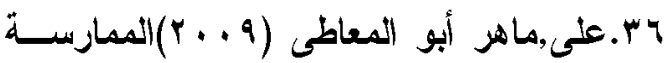

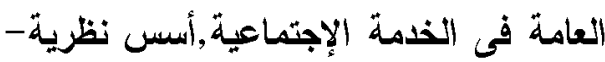

المجلة العلمية للخدمة الاجتماعية

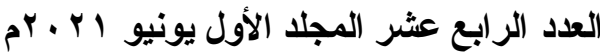

الاوليــة لقــانون البحـــار ,المركز القــومى تلإصدارات القانونية,القاهرة.

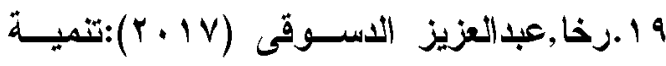

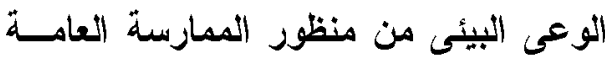

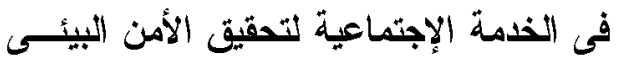

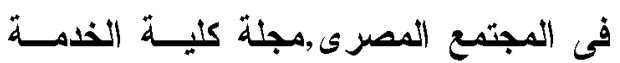

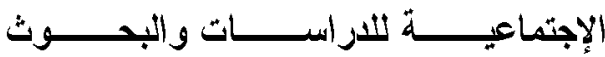
الإجتماعية, العدد التاسع, الفيوم. لإجراع

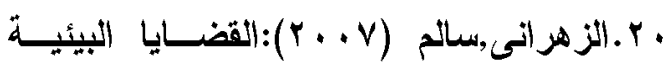

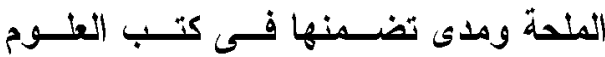

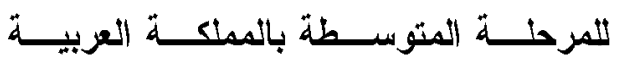

السعودية,رسالة ماجستير غير منشورة,كلية

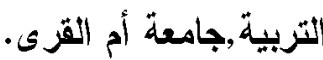

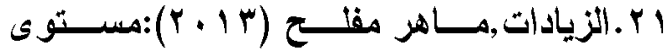

الــوعى البيئسى لـــى معلمس الدراســات

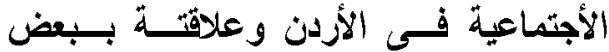

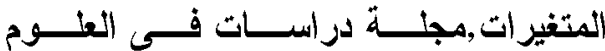

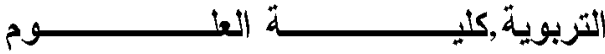
التربوية,ملحقى ؛ ,الأردن.

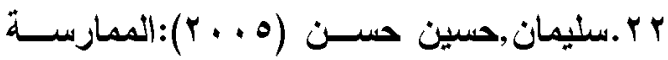

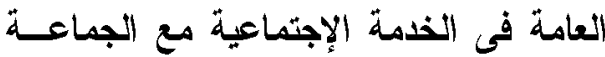

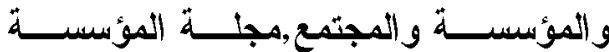

الجامعية للاز اسات والنشر و التوزيح,بيروت.

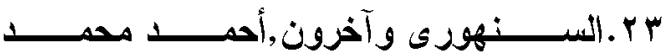

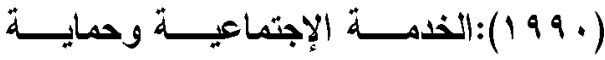
البيئة,مارينا للطباعة و النشر ,القاهرة

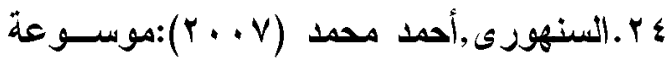

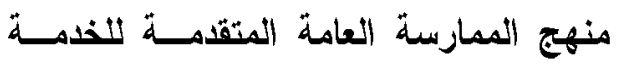

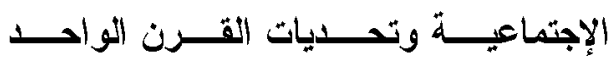
و العشرين ,الجزء الخامس. ون.

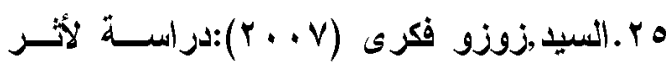
البرامج الإرشادية للفتيات الريفيات فى نقــل التوصيات الإرشادية للأسر الريفية فى مجال

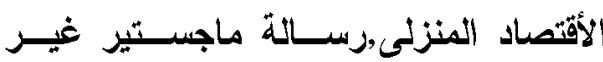
منشورة,كلية الزراعة,جامعة المنصورة. 


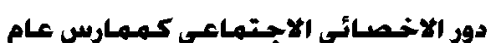

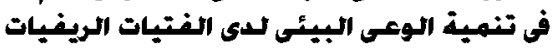

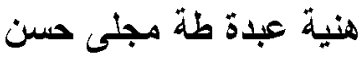

ه ؛ مختار :مصلوح,ميشيل مان ترجمة عادل ,سعد

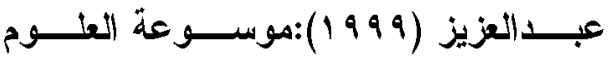
الإجتماعية,دار المعرفة الجامعية, الإسكندرية.

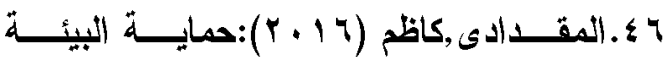
البحرية,،ركز الكتاب الأكاديمى,(د,ن) (ن).

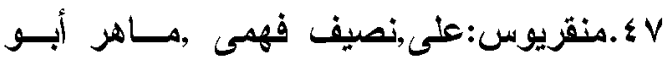
المعاطى ( . . . †):مهاز ات الممارسة المهنية للخدمة الإجتماعية,هركز نشر وتوزيع الكتاب

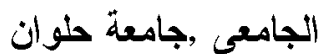

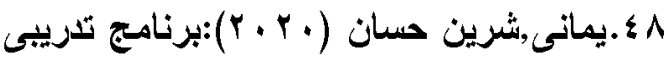

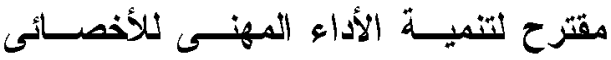

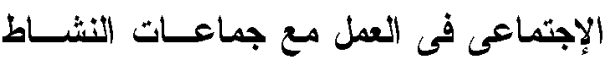

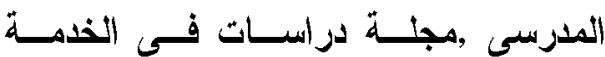

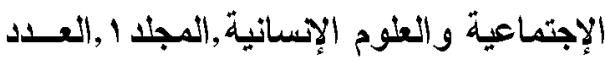

تانياً:المراجع الأجنبية:

1. chitra

singhtomar(2017):environmental awareness through education, journal of engineering and management research,p752$757, v 7$, i3, may- june.

2. eevi kokkinen(2013);measuring environmental awareness in the of oulu,teknillinen, lokaku.

3. hsiao and etal(2016);exploring the effectiveness of picture books for teaching young children the concepts of environmental protection,international research in geographical and environmental education,v25,n1, p36- 49.
نماذج تطبيقية,الكتاب العشرون,طץ,/المكتب الجامعى الحديث,الإسكندرية.

rv

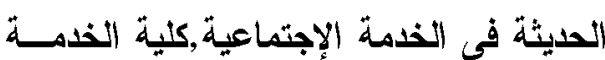

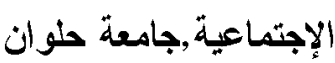

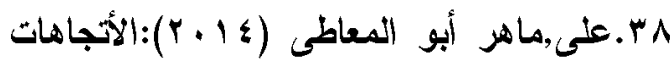
الحيثة فى البحوث الكمية والبحوث الكيفية

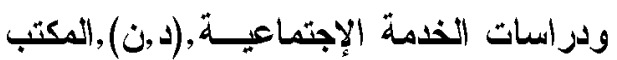

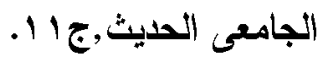

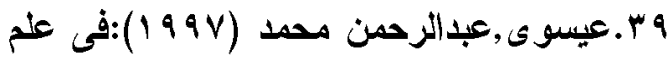

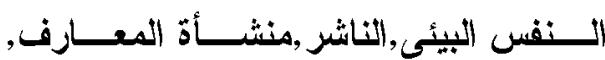

$$
\text { الإسكندرية. }
$$

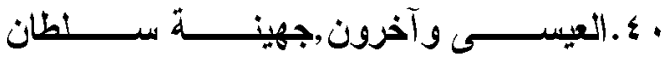

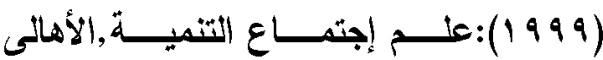

$$
\text { رمثشق. }
$$

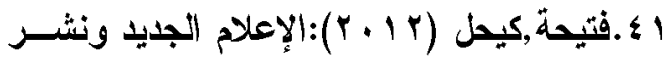

الــوعى البيئس,رســالة ماجسـتير غيـر

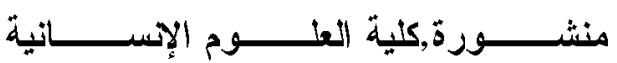
والإجتماعية,جامعة الحاج لخضر -باتنة

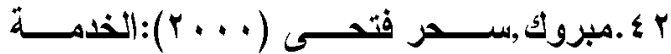

الإجنماعية فى مجال حمايــة البيئة,أسـسس نظرية وتجارب عالمية,الإسكندرية

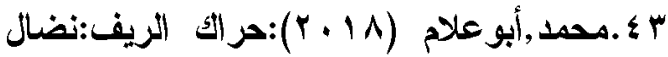

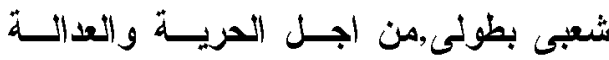
الجنماعية جمعية أطاك المغرب عضو الثبكة الدولية للجنة من أجل إلغاء الــيون غيـر

$$
\text { الثنرعية. }
$$

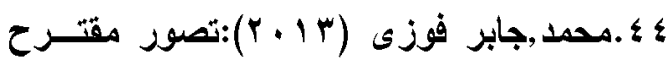

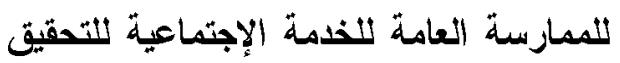
من مشـكلات الأطفــال العـاملين بالمـــن

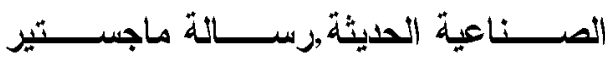
غيرمنشورة,كلية الخدمة الإجتماعية,جامعسة أسيوط 


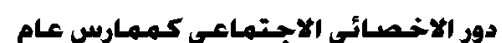

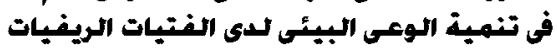

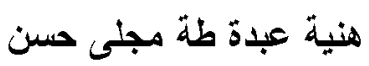

3- https://www.ida2at.com.

4- https://www.alkhaleej, ae.

5- https://ar. m. wikipedia.org.

6- index. php<www. lawoflibya.

7- https://www.com/forum/archi.

8- https://int/gobalchange/ecosy.

9- https://www.mawhopon.net.

10- https://sport- mania.net.

11- https://www.startimes.com.

12-

blo. . <www. prepschool. blogspot. com.

13- https://www.ssrcaw. org-

هركز

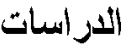

المجلة العلمية للخدمة الاجتماعية

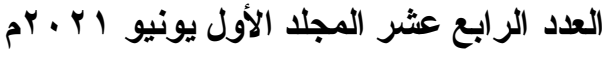

4. jubilee

pad

manabhan(2008): environmental

awareness and environmental

attitude of secondary school teachers of Maldives conference paper,J anuary.

5. kolesnik annal(2018):raising environmental awareness of future teachers nazarenko ,alexander (international journal of instruction),v11,n3,p63- 67 jul.

6. louise,c\&Stephen,j(2001):'social work practice.ageneralist approach "ally bacom,London.

7. nebrida(2019):environmental awareness and practice of science students, in put for ecological management plan,danil ov,international electronic journal of environmental education.

8. pedagogy(2016):the system of environmental education in the use fasolya,oleg,v6,n3 goessep.

9. teksoz\&etal(2012):modeling environmental literacy of university students(journal of science environmental and technology),v.12,n.1,p.p157-

166.nce students,in put for ecological.

ثالثا المواقع:

1- https://www.e3 arabi.com.

2- https://www.books.google.com.eg. 